\title{
Aerosols in the CALIOPE air quality modelling system: evaluation and analysis of PM levels, optical depths and chemical composition over Europe
}

\author{
S. Basart ${ }^{1}$, M. T. Pay ${ }^{1}$, O. Jorba ${ }^{1}$, C. Pérez ${ }^{2}$, P. Jiménez-Guerrero ${ }^{3}$, M. Schulz ${ }^{4}$, and J. M. Baldasano ${ }^{1,5}$ \\ ${ }^{1}$ Earth Sciences Department, Barcelona Supercomputing Center-Centro Nacional de Supercomputación, \\ BSC-CNS, Barcelona, Spain \\ ${ }^{2}$ NASA Goddard Institute for Space Studies and Department of Applied Physics and Applied Math, \\ Columbia University, New York, USA \\ ${ }^{3}$ Physics of the Earth, Department of Physics, University of Murcia, Murcia, Spain \\ ${ }^{4}$ Norwegian Meteorological Institute, Oslo, Norway \\ ${ }^{5}$ Environmental Modelling Laboratory, Technical University of Catalonia, Barcelona, Spain
}

Correspondence to: J. M. Baldasano (jose.baldasano@bsc.es)

Received: 29 April 2011 - Published in Atmos. Chem. Phys. Discuss.: 19 July 2011

Revised: 6 March 2012 - Accepted: 8 March 2012 - Published: 10 April 2012

\begin{abstract}
The CALIOPE air quality modelling system is developed and applied to Europe with high spatial resolution $(12 \mathrm{~km} \times 12 \mathrm{~km})$. The modelled daily-to-seasonal aerosol variability over Europe in 2004 is evaluated and analysed. Aerosols are estimated from two models, CMAQv4.5 (AERO4) and BSC-DREAM8b. CMAQv4.5 calculates biogenic, anthropogenic and sea salt aerosol and BSCDREAM8b provides the natural mineral dust contribution from North African deserts. For the evaluation, we use daily $\mathrm{PM}_{10}, \mathrm{PM}_{2.5}$ and aerosol components data from 55 stations of the EMEP/CREATE network and total, coarse and fine aerosol optical depth (AOD) data from 35 stations of the AERONET sun photometer network. Annual correlations between modelled and observed values for $\mathrm{PM}_{10}$ and $\mathrm{PM}_{2.5}$ are 0.55 and 0.47 , respectively. Correlations for total, coarse and fine AOD are 0.51, 0.63, and 0.53, respectively. The higher correlations of the $\mathrm{PM}_{10}$ and the coarse mode AOD are largely due to the accurate representation of the African dust influence in the forecasting system. Overall PM and AOD levels are underestimated. The evaluation of the aerosol components highlights underestimations in the fine fraction of carbonaceous matter (EC and OC) and secondary inorganic aerosols (SIA; i.e. nitrate, sulphate and ammonium). The scores of the bulk parameters are significantly improved after applying a simple model bias correction based on the observed aerosol composition. The simulated $\mathrm{PM}_{10}$ and $\mathrm{AOD}$ present maximum values over the in-
\end{abstract}

dustrialized and populated Po Valley and Benelux regions. SIA are dominant in the fine fraction representing up to $80 \%$ of the aerosol budget in latitudes north of $40^{\circ} \mathrm{N}$. In southern Europe, high $\mathrm{PM}_{10}$ and $\mathrm{AOD}$ are linked to the desert dust transport from the Sahara which contributes up to $40 \%$ of the aerosol budget. Maximum seasonal ground-level concentrations $\left(\mathrm{PM}_{10}>30 \mu \mathrm{g} \mathrm{m}^{-3}\right)$ are found between spring and early autumn. We estimate that desert dust causes daily exceedances of the $\mathrm{PM}_{10}$ European air quality limit value $\left(50 \mu \mathrm{g} \mathrm{m}^{-3}\right)$ in large areas south of $45^{\circ} \mathrm{N}$ with more than 75 exceedances per year in the southernmost regions.

\section{Introduction}

Atmospheric aerosols or particulate matter (PM) are highly variable in space and time due to the variety of their sources and their fast removal from the atmosphere (from days to weeks). Aerosols contribute to adverse human health effects (WHO, 2005), including increased morbidity and mortality arising from altered respiratory and cardiovascular function (Pope et al., 2009; Medina et al., 2009) and have a significant, yet uncertain effect on climate from regional to global scales (IPCC, 2007). To understand the wide-ranging effects of aerosols, it is important to characterize them with high spatial and temporal resolution. 
The European Union (EU) directive on ambient air quality and cleaner air, which came into force in June 2008 and was transposed into the national legislation of each Member State by June 2010 (European Commission, 2008), introduced daily and annual $\mathrm{PM}_{10}$ limit values of $50 \mu \mathrm{g} \mathrm{m}^{-3}$ and $40 \mu \mathrm{g} \mathrm{m}^{-3}$, respectively, from year 2010. Also this directive introduces a $\mathrm{PM}_{2.5}$ annual limit value of $25 \mu \mathrm{g} \mathrm{m}^{-3}$ to be assumed from year 2015. In this regard, the objectives proposed by the EU are usually less well attained in southern Europe than in northern countries (Yttry and Aas, 2006). Reports from countries around the Mediterranean Basin and Eastern Europe show high levels of atmospheric PM compared to Northern regions and some central European regions (Querol et al., 2009). Both anthropogenic (transport sector, industrial processes, power generation and biomass burning, among others) and natural emissions (African dust, resuspension, sea spray, forest fires, primary biological particles and biogenic secondary organic compounds, windblown dust), as well as orographic and climatic factors contribute to the ocurrence of (or cause) those enhanced levels. When $\mathrm{PM}_{10}$ values are exceeded due to natural events (such as desert dust outbreaks or volcano eruptions), Member States shall inform the Commission, providing the necessary justification to demonstrate that such exceedances are due to natural events.

Air quality models are useful to understand and predict the dynamics and transport of pollutants. In recent years a number of experimental and operational air quality forecast systems have been developed around the world. Nowadays, in Europe, 23 modelling systems routinely simulate the air quality over Europe, 7 systems also operate in forecasting mode (Menut and Bessagnet, 2010): PREV'AIR, EURAD, EMEP-CWF, MATCH, MOCAGE, CHIMERE, and CALIOPE.

In the frame of the CALIOPE system (Baldasano et al., 2008a; http://www.bsc.es/caliope), the Barcelona Supercomputing Center-Centro Nacional de Supercomputación (BSC-CNS) operates an air quality forecasting system for Spain (at $4 \mathrm{~km} \times 4 \mathrm{~km}$ horizontal resolution) and $\mathrm{Eu}-$ rope (at $12 \mathrm{~km} \times 12 \mathrm{~km}$ horizontal resolution) with WRFARW/HERMES-EMEP/CMAQ and desert dust forecasts with BSC-DREAM8b (Nickovic et al., 2001; Pérez et al., 2006a, b). In contrast to many other European modelling systems, CALIOPE includes a non-climatic representation of Saharan dust transport in its forecast mode. The forecasts are evaluated on a daily and hourly against ground-based and satellite observations to establish confidence in the modelling system predictions among users, identify problems and routinely improve the system (Baldasano et al., 2010).

Pay et al. (2010) presented a full year evaluation of the CALIOPE system for the European domain for gaseous pollutants $\left(\mathrm{O}_{3}, \mathrm{NO}_{2}\right.$ and $\left.\mathrm{SO}_{2}\right)$ and $\mathrm{PM}$ levels $\left(\mathrm{PM}_{10}\right.$ and $\mathrm{PM}_{2.5}$ ) against EMEP ground-based measurements. The study shows that the skill scores of the system lie within the range of most European models and that while the dynamics of $\mathrm{PM}_{2.5}$ and $\mathrm{PM}_{10}$ are rather well reproduced, concentra- tions remain systematically underestimated by a factor of 2 on average.

The main objective of the present work is to complement the results of the PM evaluation presented in Pay et al. (2010) by (1) providing a detailed quantitative assessment of the capabilities of the CALIOPE system to simulate the daily aerosol distribution over Europe for year 2004 in terms of PM levels, aerosol optical depth (AOD) and chemical composition; (2) understanding the underestimation of the PM mass; (3) estimating and analysing the spatial and seasonal distribution of the different aerosol fractions over Europe based on model results and observations; and (4) estimating the exceedances of the EU limits due to natural desert dust.

The manuscript is organized as follows. Section 2 describes the CALIOPE system and the observational datasets used for the model evaluation. In Sect. 3 we use aerosol chemical composition from EMEP/CREATE and AOD from the AERONET network to identify the origin of the discrepancies in PM levels. The evaluation of the AOD is particularly useful for validating and analysing the capabilities of the modelling system to reproduce long-range transport of desert dust from North Africa. In Sect. 4 we estimate and analyse the spatial and seasonal distribution of the different natural and anthropogenic aerosol fractions over Europe by applying a simple bias correction to the model based on the results of the evaluation. African dust transport and its contribution over Europe are analysed in detail. Finally, Sect. 5 summarizes the main findings of the study.

\section{Methods}

\subsection{Description of the CALIOPE system}

CALIOPE is a state-of-the-art air quality modelling system that integrates an emission-processing model (HERMESEMEP), a meteorological model (WRF-ARW), a chemical transport model (CMAQ) and a mineral dust model (BSCDREAM8b). The configuration used in this work is described in Pay et al. (2010). In the sections below, the models utilized to estimate aerosols (i.e. CMAQ and BSCDREAM8b) are described in detail.

\subsubsection{Photochemical model: CMAQ}

The Models-3 Community Multiscale Air Quality Modeling system (CMAQ; Byun and Ching, 1999; Binkowski, 1999; Byun and Schere, 2006) is used to study the behaviour of air pollutants from regional to local scales. The CMAQ version 4.5 used in this study has been extensively evaluated under various conditions and locations (Jiménez et al., 2003; Roy et al., 2007; Appel et al., 2007, 2008). Following the criteria of Jiménez et al. (2003) the Carbon Bond IV chemical mechanism is applied (CBM-IV, Gery et al., 1989). The production of sea salt aerosol (SSA) is implemented as a function of wind speed and relative humidity 
(Gong, 2003; Zhang et al., 2005) through the AERO4 aerosol module. The AERO4 module distinguishes among different chemical aerosol components namely nitrate, sulphate, ammonium, elemental carbon and organic carbon with three subcomponents (primary, secondary anthropogenic and secondary biogenic), sodium and chlorine. Unspecified anthropogenic aerosols and aerosol water are additionally kept as separate components. Unspecified aerosols consist of noncarbon atoms associated with organic carbon as well as PM emissions that are not explicitly speciated in the HERMESEMEP emission model, which includes traces elements, primary ammonium and other unidentified mass in the speciation profiles (Appel et al., 2007). Aerosols are represented by three size modes (Aitken, accumulation and coarse mode), each of them assumed to have a lognormal distribution (Binkowski and Roselle, 2003). Secondary inorganic aerosols (SIA) are generated by nucleation processes and consists of nitrate, ammonium and sulphate aerosols. Secondary organic aerosol (SOA) can be formed from aromatics (anthropogenic organic aerosols) and terpenes (biogenic organic aerosols; Schell et al., 2001). An assumption of the CMAQv4.5 model is that organics influence neither the water content nor the ionic strength of the aerosol particles (Binkowski and Roselle, 2003). The aerosol microphysical description is based on a modal aerosol model (Binkowski and Roselle, 2003) using the ISORROPIA thermodynamic equilibrium model (Nenes et al., 1998). For a more complete description of the processes implemented in CMAQ, the reader is referred to Byun and Schere (2006).

AOD at $550 \mathrm{~nm}$ from CMAQ outputs is calculated using a simple approach described by Malm et al. (1994) and Binkowski and Rosselle (2003). The method is known as the "reconstructed mass-extinction method". The extinction coefficient $\left(\beta_{\text {ext }}\right)$, which is a function of wavelength $(\lambda)$, is a sum of the attenuation by scattering $\left(\beta_{\mathrm{s}}\right)$ and absorption $\left(\beta_{\mathrm{a}}\right)$. The model-predicted AOD is calculated by summing the product of the extinction and layer thickness $\left(\Delta Z_{i}\right)$ over the number of layers $(N)$ in the column:

$\mathrm{AOD}=\sum_{i=1}^{N}\left(\beta_{\mathrm{s}}+\beta_{\mathrm{a}}\right)_{i} \Delta \mathrm{Z}_{i}$

We estimate the model-predicted $\beta_{\mathrm{ext}}=\beta_{\mathrm{s}}+\beta_{\mathrm{a}}$ using this semi-empirical approach for extinction calculation which depends on aerosol mass and humidity as follows:

$$
\begin{aligned}
\beta_{\mathrm{s}} & =0.003 f(\mathrm{RH})\left\{\left[\mathrm{NH}_{4}^{+}\right]+\left[\mathrm{SO}_{4}^{2-}\right]+\left[\mathrm{NO}_{3}^{-}\right]\right\} \\
& +0.004[\mathrm{OC}]+0.001\left[\mathrm{PM}_{\text {fine }}\right]+0.0006\left[\mathrm{PM}_{\text {coarse }}\right] \\
\beta_{\mathrm{a}} & =0.01[\mathrm{EC}]
\end{aligned}
$$

where the brackets in the above equations indicate mass concentration in $\mathrm{mg} \mathrm{m}^{-3}$ and all coefficients in the equation represent the specific extinction cross section at $550 \mathrm{~nm}$ (in $\mathrm{m}^{2} \mathrm{mg}^{-1}$ ). When implementing the aforementioned equation, the term in brackets is determined by adding ammonium mass $\left(\mathrm{NH}_{4}^{+}\right)$plus sulphate mass $\left(\mathrm{SO}_{4}^{2-}\right)$ plus nitrate mass $\left(\mathrm{NO}_{3}^{-}\right)$. Organic carbon $(\mathrm{OC})$ is taken as the sum of all non-light absorbing organic species. Light absorbing carbon is elemental carbon (EC). $\mathrm{PM}_{\text {fine }}$ mass is taken as the unspeciated portion of $\mathrm{PM}_{2.5}$ and the fine fraction of sodium $\left(\mathrm{Na}^{+}\right)$and chloride $\left(\mathrm{Cl}^{-}\right)$, and the $\mathrm{PM}_{\text {coarse }}$ mass represents all coarse mode aerosols that includes the unspeciated portion of $\mathrm{PM}_{10}$ and the coarse fraction of sodium $\left(\mathrm{Na}^{+}\right)$and chloride $\left(\mathrm{Cl}^{-}\right)$. The mass concentration for each of these species is directly obtained from CMAQ. The relative humidity correction factor, $f(\mathrm{RH})$, takes into account that the growth and phase change of hygroscopic particles affect their light-scattering effiency (Malm et al., 1994). $f(\mathrm{RH})$ is parameterized from data published by Tang et al. (1981) as a function of the relative humidity from the WRF-ARW meteorological model and it varies between 1 (at low RH) and 21 (at $\mathrm{RH}=99 \%$ ).

\subsubsection{Mineral dust model: BSC-DREAM8b}

The Dust REgional Atmospheric Model (DREAM; Nickovic et al., 2001) was designed to simulate and/or predict the atmospheric cycle of mineral dust. The updated model version BSC-DREAM8b used here is described in Pérez et al. (2006a, b). It includes an 8-bins size distribution within the $0.1-10 \mu \mathrm{m}$ radius range according to Tegen and Lacis (1996).

The BSC-DREAM8b model has demonstrated its capabilities in a number of validation studies performed so far using data from observation networks such as the European Lidar Network EARLINET, the AERONET/PHOTONS sunphotometer network, satellite and ground-level PM levels (e.g. Pérez et al., 2006a; Amiridis et al., 2009; Papanastasiou et al., 2010). Such validations outline the good skills of the model concerning both the horizontal and vertical extent of the dust plume in Europe and the Mediterranean Basin. Additionally, the model has been validated and tested against measurements at source regions for SAMUM-I (Haustein et al., 2009) and BODEX campaigns (Todd et al., 2008).

In BSC-DREAM8b, the AOD is calculated from the column mass loading by:

$\operatorname{AOD}(\lambda)=\sum_{k=1}^{8} \operatorname{AOD}_{k}(\lambda)=\sum_{k=1}^{8} \frac{3}{4 \rho_{k} r_{k}} M_{k} Q_{\text {ext }}(\lambda)_{k}$

where for each size bin $k: \rho_{k}$ is the particle mass density, $r_{k}$ is the effective radius, $M_{k}$ is the column mass loading and $Q_{\text {ext }}(\lambda)_{k}$ is the extinction efficiency which is calculated using Mie scattering theory.

\subsection{Simulation}

The CALIOPE system is run at $12 \mathrm{~km} \times 12 \mathrm{~km}$ grid resolution covering the European domain (Fig. 1). The simulation consists of 366 daily runs covering an annual cycle (2004).

CALIOPE uses an inventory of anthropogenic emissions of $\mathrm{SO}_{2}, \mathrm{NO}_{\mathrm{x}}, \mathrm{NMVOC}, \mathrm{CO}, \mathrm{PM}_{10}, \mathrm{PM}_{2.5}$, and $\mathrm{NH}_{3}$ derived 


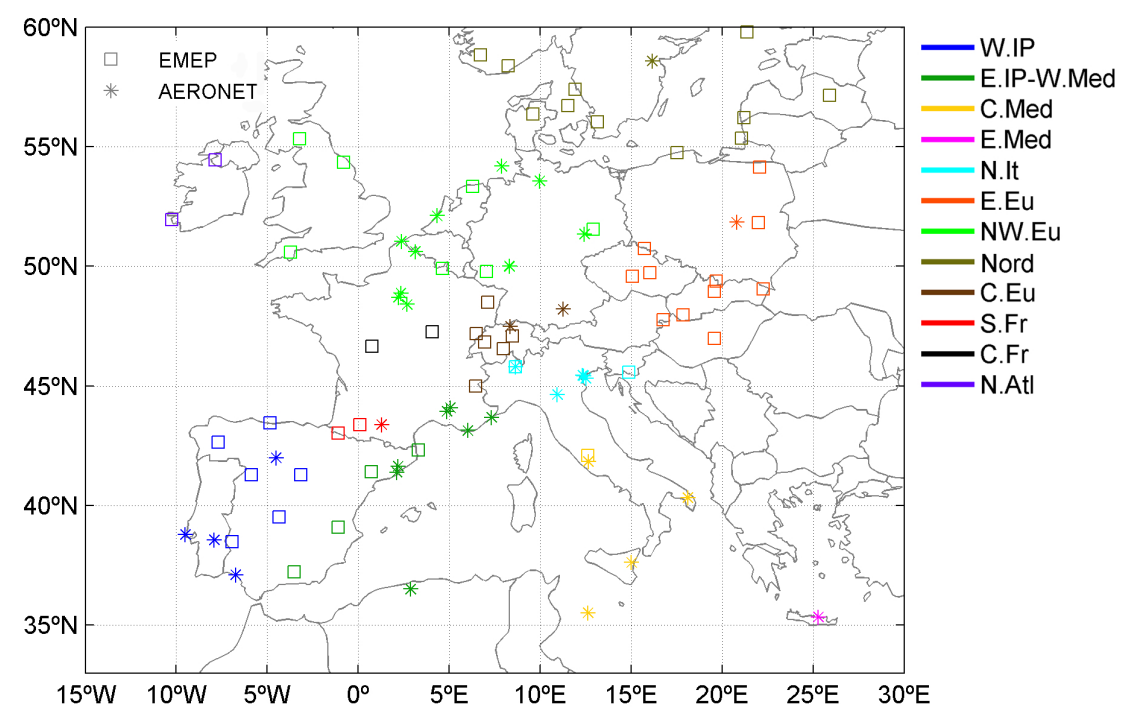

Fig. 1. Study domain and spatial distribution of 55 selected EMEP stations (squares) and 35 selected AERONET stations (stars). The different colours indicate the different regions which are defined as: Western Iberian Peninsula (W.IP); Eastern Iberian Peninsula-Western Mediterranean (E.IP-W.Med), Central Mediterranean (C.Med), Eastern Mediterranean (E.Med), North of Italy (N.It), Eastern Europe (E.Eu), Northwestern Europe (NW.Eu), Southern France (S.Fr), Central Europe (C.Eu), Nordic (Nord), Central France (C.Fr) and North Atlantic (N.Atl).

from the 2004 annual EMEP emission database (EMEP, 2007). Raw emission data are processed by the HighElective Resolution Modeling Emission System (HERMES, see Baldasano et al., 2008b) in order to include a comprehensive set of emissions in the air quality model. The inventory distinguishes the source categories following the Selected Nomenclature Air Pollution (SNAP). Disaggregation of EMEP (50 km resolution) data is performed in space $(12 \mathrm{~km} \times 12 \mathrm{~km})$ and time $(1 \mathrm{~h})$. Natural PM emissions (such as wildfire emissions) and primary biogenic emissions (such as pollen, bacteria, fungal, and fern spores, viruses, fragments of animals and plants, etc.) containing organic compounds are not included in the emission model.

The Advanced Research Weather Research and Forecasting (WRF-ARW) Model v3.0.1.1 (Michalakes et al., 2004; Skamarock and Klemp, 2008) is used to provide the meteorology to the chemical transport model. WRF-ARW v3.0.1.1 is configured with a grid of $479 \times 399$ points and $38 \sigma$ vertical levels (11 characterizing the PBL). The model top is defined at $50 \mathrm{hPa}$ to resolve properly troposphere-stratosphere exchanges. WRF-ARW initial and boundary conditions at intervals of $6 \mathrm{~h}$ are based on the Final Analyses of the National Centers of Environmental Prediction (FNL/NCEP; at $1^{\circ} \times 1^{\circ}$ ) at 12:00 UTC.

The CMAQ horizontal grid resolution corresponds to that of WRF-ARW. Its vertical structure was obtained by a collapse from the 38 WRF-ARW layers to a total of 15 layers steadily increasing from the surface up to $50 \mathrm{hPa}$ with a stronger concentration within the PBL. CMAQ boundary coditions for gas-phase species are based on the global climate chemistry model LMDz-INCA2 (Szopa et al., 2009) developed by the Laboratoire des Sciences du Climat et l'Environnement (LSCE). Monthly mean data for the year 2004 are interpolated in the horizontal and vertical dimensions to force the major chemical concentrations (i.e. $\mathrm{O}_{3}$, $\mathrm{NO}, \mathrm{NO}_{2}, \mathrm{HNO}_{3}, \mathrm{HCHO}, \mathrm{H}_{2} \mathrm{O}_{2}, \mathrm{PAN}$ and $\mathrm{CO}$ ) at the boundaries of the domain (Piot et al., 2008). A detailed description of the INteractive Chemistry and Aerosol (INCA) model is presented in Hauglustaine et al. (2004) and Folberth et al. (2006).

The initial state of dust concentration in the BSCDREAM $8 \mathrm{~b}$ model is defined by the 24 - $\mathrm{h}$ forecast from the previous-day model run. The FNL/NCEP $\left(\right.$ at $1^{\circ} \times 1^{\circ}$ ) at 00:00 UTC are used as initial conditions and boundary conditions at intervals of $6 \mathrm{~h}$. The resolution is set to $1 / 3^{\circ}$ in the horizontal and to 24 layers extending up to approximately $15 \mathrm{~km}$ in the vertical. The domain of simulation covers northern Africa, the Mediterranean Sea, southern Europe and Middle East. An offline coupling is applied to the calculated concentrations of PM over the European domain from CMAQ outputs (Jiménez-Guerrero et al., 2008). 


\subsection{Observations}

\subsubsection{Surface PM and chemical composition from EMEP/CREATE Networks}

In this study, simulated PM concentrations are compared with ground-based measurements from the European Monitoring and Evaluation Programme (EMEP) monitoring network for year 2004. EMEP stations are located at a minimum distance of approximately $10 \mathrm{~km}$ from large emission sources (Larssen et al., 1999). EMEP stations are assumed to be representative of regional background concentrations (Torseth and Hov, 2003). A total of 17 and 26 stations for $\mathrm{PM}_{2.5}$ and $\mathrm{PM}_{10}$ respectively have been used to evaluate the model predictions. Details on the location of the EMEP stations used for this comparison can be found in Appendix Table A1.

Modelled aerosol concentrations of chemical species are compared with ground-based measurements provided by EMEP and the FP5/GMES project CREATE at 55 rural background stations. The uncertainty of PM measurements strongly depends on the method and chemical composition of the collected aerosol. Usually the collected filters are weighted at $50 \%$ relative humidity (Tsyro, 2005). Error sources leading to a bias are potential losses of semivolatile compounds (particularly ammonium nitrate and carbonaceous aerosols) from the filters at temperatures higher than $20^{\circ} \mathrm{C}$ as well as gas condensation on filters which could introduce positive measurements artefacts. SIA components can be measured with an uncertainty of about $\pm 10 \%$ for major species (Putaud et al., 2004). In this context, European legislation (2008/50/EC) establishes that measurement groups have to demonstrate that the uncertainty of $\mathrm{PM}_{10}$ and $\mathrm{PM}_{2.5}$ meets the quality objective of $25 \%$. However legislation does not establish any quality objective for uncertainty of chemical species yet. SIA components collected within CREATE are measured by ion chromatography in which the error is usually within $10 \%$ (Putaud et al., 2000).

One source of underestimation of SIA components is related to the size fraction of aerosol components in both measurements and the model. The observed concentrations are available as total mass, without any discrimination of size since EMEP sites typically used filter-packs to measure sulphate, nitrate and ammonium and captured particles that are approximately in the $\mathrm{PM}_{10}$ fraction. Conversely, the CMAQv4.5 model considers speciated inorganic aerosol only in the $\mathrm{PM}_{2.5}$ fraction. One exception is marine sulphate aerosol which is present also in the coarse fraction. The comparison of carbonaceous matter is conducted using the $\mathrm{PM}_{2.5}$ fraction of the modelled and measured values.

In the present work, measured $\mathrm{PM}_{10}, \mathrm{PM}_{2.5}$ and their chemical aerosol components (i.e. sulphate, nitrate, ammonium, sea salt and carbonaceous matter) are available on a daily (except at Birkenes station for EC and OC that is available on a weekly basis). The main characteristics and location of EMEP/CREATE stations are described in Ap- pendix A1 and their locations are displayed in Fig. 1. The CALIOPE system is evaluated at 55 stations: 54 for sulphate $\left(\mathrm{SO}_{4}^{2-}\right), 28$ for nitrate $\left(\mathrm{NO}_{3}^{-}\right), 16$ for ammonium $\left(\mathrm{NH}_{4}^{+}\right), 10$ for sodium $\left(\mathrm{Na}^{+}\right), 6$ for chloride $\left(\mathrm{Cl}^{-}\right)$and 3 for carbonaceous matter (EC and OC). The measurements are well documented and available on the EMEP web page (http://www.emep.int).

\subsubsection{Aerosol optical depth from AERONET Network}

The optical properties of the aerosol in the entire atmospheric column are routinely observed within the Aerosol Robotic Network (AERONET, Holben et al., 1998; Smirnov et al., 2000). The network imposes standardization of instruments, calibration, processing and distribution.

Sun photometer measurements of the direct (collimated) solar radiation provide information to calculate the columnar AOD. The typical uncertainty in the direct-sun AOD measurements ranges from 0.01 to 0.02 with higher errors in the ultraviolet spectral range (Dubovik et al., 2000). Additionally, direct-sun AOD processing includes the Spectral Deconvolution Algorithm (SDA) retrievals (O'Neill et al., 2003). The SDA algorithm yields fine (sub-micron) and coarse (super-micron) AOD at a standard wavelength of $500 \mathrm{~nm}\left(\mathrm{AOD}_{\text {fine }}\right.$ and $\mathrm{AOD}_{\text {coarse }}$, respectively). The amplitude of the errors of the derived parameters varies as the inverse of the total AOD. In addition to measurement errors, there are errors in the AOD retrieval due to the uncertainty in the assumed values of the spectral curvature in each mode (O'Neill et al., 2001) which are most critical in coarse mode dominated conditions.

All operational stations within our target domain that collected data on at least $30 \mathrm{~h}$ in 2004 have been selected for the model evaluation. Appendix A2 and Fig. 1 describe and show the location and the main characteristics of the 35 selected AERONET sites within our study region. Appendix A2 lists additional information including type of site, observation periods, percentage of cloud-screened data and the availability of SDA products.

Quality-assured direct-sun data in the $440-870 \mathrm{~nm}$ wavelength range is used to calculate the AOD at $550 \mathrm{~nm}$ obtained by the Ångström's equation adjustment. The contribution of each aerosol fraction is analysed using the SDA retrieval products $\left(\mathrm{AOD}_{\text {fine }}\right.$ and $\left.\mathrm{AOD}_{\text {coarse }}\right)$.

\section{Model evaluation}

There is a number of metrics that can be used to examine performances of air quality models (US EPA, 1984, 1991; Cox and Tikvart, 1990; Weil et al., 1992; Chang and Hanna, 2004; Boylan and Russell, 2006; Dennis et al., 2010). Correlation coefficient $(r)$, root mean squared error (RMSE), mean bias (MB) and mean normalized bias error (MNBE) are commonly used by the modelling community. For the evaluation 
of PM concentrations, Boylan and Russell (2006) suggested the mean fractional bias (MFB) and the mean fractional error (MFE). Additionally, they propose model performance goals (the level of accuracy that is considered to be close to the best a model can be expected to achieve) and criteria (the level of accuracy that is considered to be acceptable for modelling applications) that vary as a function of concentration and extinction. A model performance goal is met when both MFE and MFB are less than or equal to $50 \%$ and $\pm 30 \%$, respectively, and a model performance criterion is met when both MFE and MFB are less than or equal to $75 \%$ and $60 \%$, respectively. The model-to-data statistics MB, MNBE, RMSE, MFE and MFB are selected for the present study, together with the measured and modelled mean and the correlation coefficient. A description of these statistics is included in Appendix A3. Comparisons are made for annual and monthly basis as well as 4 seasonal periods: winter (DJF) corresponding to December, January and February, spring (MAM) corresponding to March, April and May, summer (JJA) corresponding to June, July, August and autumn (SON) corresponding to September, October and November. Measured $\mathrm{PM}_{10}, \mathrm{PM}_{2.5}$ and their chemical aerosol components (i.e. sulphate, nitrate, ammonium, sea salt and carbonaceous matter) from EMEP/CREATE networks are used for the model comparison on a daily basis (except Birkenes station for EC and $\mathrm{OC}$ ). Moreover, since AERONET data are acquired at 15-min intervals on average, all AERONET measurements within $\pm 30 \mathrm{~min}$ of the model outputs have been extracted and used for the model comparison on an hourly and daily basis.

Since differences in the comparison between simulations and observations are rather small among sites located in the same region, statistical indicators have been averaged over the regions indicated in Fig. 1 by colours and defined in Appendix $\mathrm{A} 1$ and $\mathrm{A} 2$.

\subsection{Ground level $\mathbf{P M}_{2.5}$ and $\mathbf{P M}_{10}$ concentrations}

Before evaluating PM composition, it is important to ensure that reactive gases are well reproduced, since a major fraction of ambient PM arises from atmospheric gas-to-particle conversion (Meng et al., 1997). In Pay et al. (2010) the CALIOPE model output for gas and particulate phase concentrations are compared with ground-based measurements from the EMEP monitoring network for year 2004 over Europe. The evaluation showed that the modelling system is able to reproduce reasonably well daily variations of gas phase pollutants $\left(\mathrm{SO}_{2}, \mathrm{NO}_{2}\right.$ and $\left.\mathrm{O}_{3}\right)$ as well as their spatial distribution and seasonal cycle.

Table 1 and Fig. 2a, b and f, g depict the annual and seasonal statistical results of the evaluation of PM and the allEuropean time series of the model and observations calculated on a daily basis. The model presents a systematic negative bias for $\mathrm{PM}_{2.5}$ and $\mathrm{PM}_{10}$ (annual $\mathrm{MB}=-6.45 \mu \mathrm{g} \mathrm{m}^{-3}$ and $-10.23 \mu \mathrm{g} \mathrm{m}^{-3}$, respectively), although it is able to re- produce the daily variability through the year with correlation of 0.47 and 0.55 , respectively (Fig. 2a, b).

The modelled coarse fraction includes the contribution of unspeciated anthropogenic mass, sea salt and desert dust. One source of uncertainty in the $\mathrm{PM}_{10}$ comparison comes from the assumption of dry and inert coarse mode aerosols in CMAQv4.5 with the AERO4 aerosol module. Several studies in Spain and the Mediterranean (e.g. Rodríguez et al., 2002; Querol et al., 2004, 2009) suggest that between mid-spring and mid-autumn most nitrate is present as calcium and/or sodium salts in the $2.5-10 \mu \mathrm{m}$ fraction. Other potential forms of nitrate and sulphate, such as salts linked to the reaction of acid pollutants with dust (Rodríguez et al., 2002; Querol et al., 2004, 2009) are not considered in the simulated $\mathrm{PM}_{10}$. Higher $\mathrm{PM}_{10}$ correlations are observed in summertime over southern European stations affected by Saharan dust outbreaks (see Fig. 3). The modelled desert dust contributions in the $\mathrm{PM}_{2.5}$ and $\mathrm{PM}_{10}$ fractions are on average $20 \%$ and $25 \%$, respectively, increasing to $33 \%$ and $35 \%$ in the Mediterranean stations. Although the model calculates a considerable contribution of dust on both $\mathrm{PM}_{2.5}$ and $\mathrm{PM}_{10}$, a higher annual correlation is observed in the $\mathrm{PM}_{10}$ fraction. Pay et al. (2011) shows that despite the total dust mass is reasonably well captured by the BSC-DREAM8b model, it tends to overestimate the fine dust fraction $(<2.5 \mu \mathrm{m})$.

Overall, the skills achieved by CALIOPE are in the range of those shown in other European modelling studies (see Sect. 4 of the work of Pay et al., 2010). However, the MFE and MFB for $\mathrm{PM}_{2.5}$ and $\mathrm{PM}_{10}$ do not meet the performance criteria proposed by Boylan and Russell (2006). Many studies have recognized the difficulty of models to simulate the mass of PM over Europe (e.g. Matthias, 2008; Pay et al., 2010). The underestimation of $\mathrm{PM}_{10}$ is, among others, the result of a lack of fugitive dust emissions, resuspended matter, a possible underestimation of primary carbonaceous particles, the inaccuracy of SOA formation, the difficulty of representing primary PM emission from wood burning and other sources not considered in the emission inventory as pollutant sources over North Africa (Rodríguez et al., 2011) and a more general lack of process knowledge on aerosol removal and dispersion and transport processes.

\subsection{PM chemical composition}

Chemical composition measurements can help to identify model limitations in simulating the physical and chemical processes leading to the formation of SIA (namely, sulphate, nitrate and ammonium), SOA and SSA. For the sake of comparison with EMEP stations different size modes are lumped to obtain the total sulphate (Aitken, accumulation and coarse modes), nitrate (Aitken, accumulation and coarse modes), ammonium (Aitken and accumulation modes), chloride and sodium (accumulation and coarse modes) and carbonaceous matter concentration (i.e. organic and elemental carbon). Table 1, Fig. 2c-e, Fig. $2 \mathrm{~h}-\mathrm{j}$ and Fig. 3 show the 
Table 1. Seasonal and annual statistics obtained with CALIOPE over Europe for 2004 at the EMEP/CREATE stations for SIA (i.e. sulphate, nitrate, and ammonium) and SSA (i.e. chloride and sodium). Winter: January, February and December; spring: March, April, May; summer: June, July, August; autumn: September, October, November. The number of data points indicates the number of pair measurement-model used to compute the statistics. The calculated statistics are: measured mean for available data, modelled mean for the whole year, correlation coefficient $(r)$, mean bias (MB), mean normalize bias error (MNBE), root mean square error (RMSE), mean fractional bias (MFB) and mean fractional error (MFE).

\begin{tabular}{|c|c|c|c|c|c|c|c|c|c|c|}
\hline & & $\begin{array}{r}\text { Data } \\
\text { Points }\end{array}$ & $\begin{array}{r}\text { Obs. Mean } \\
\left(\mu \mathrm{g} \mathrm{m}^{-3}\right)\end{array}$ & $\begin{array}{c}\text { Mod. Mean } \\
\left(\mu \mathrm{g} \mathrm{m}^{-3}\right)\end{array}$ & $r$ & $\begin{array}{r}\mathrm{MB} \\
\left(\mu \mathrm{g} \mathrm{m}^{-3}\right)\end{array}$ & $\begin{array}{r}\text { MNBE } \\
(\%)\end{array}$ & $\begin{array}{r}\text { RMSE } \\
\left(\mu \mathrm{g} \mathrm{m}^{-3}\right)\end{array}$ & $\begin{array}{r}\text { MFB } \\
(\%)\end{array}$ & $\begin{array}{r}\text { MFE } \\
(\%)\end{array}$ \\
\hline \multirow{5}{*}{$\begin{array}{l}\mathrm{PM}_{2.5} \text { daily } \\
\text { (17 stations) }\end{array}$} & Annual & 5443 & 12.5 & 6.0 & 0.47 & -6.45 & -45.6 & 11.2 & -72 & 80 \\
\hline & Winter & 1258 & 13.7 & 5.2 & 0.62 & -8.47 & -47.5 & 15.1 & -78 & 86 \\
\hline & Spring & 1344 & 12.3 & 5.4 & 0.50 & -6.85 & -50.1 & 10.6 & -79 & 84 \\
\hline & Summer & 1468 & 12.4 & 6.8 & 0.49 & -5.59 & -45.4 & 9.1 & -71 & 78 \\
\hline & Autumn & 1373 & 11.6 & 6.6 & 0.52 & -5.06 & -39.2 & 9.3 & -62 & 71 \\
\hline \multirow{5}{*}{$\begin{array}{l}\mathrm{PM}_{10} \text { daily } \\
\text { (26 stations) }\end{array}$} & Annual & 8722 & 17.8 & 7.6 & 0.55 & -10.23 & -49.1 & 15.8 & -78 & 84 \\
\hline & Winter & 2075 & 17.9 & 6.8 & 0.54 & -11.10 & -47.1 & 18.1 & -78 & 86 \\
\hline & Spring & 2167 & 17.6 & 7.3 & 0.50 & -10.32 & -52.2 & 15.0 & -83 & 87 \\
\hline & Summer & 2276 & 18.7 & 8.0 & 0.59 & -10.71 & -53.9 & 16.3 & -83 & 85 \\
\hline & Autumn & 2190 & 17.1 & 8.3 & 0.61 & -8.76 & -42.6 & 13.3 & -68 & 76 \\
\hline \multirow{5}{*}{$\begin{array}{l}\text { Sulphate daily } \\
\text { ( } 54 \text { stations) }\end{array}$} & Annual & 18391 & 1.7 & 1.4 & 0.49 & -0.30 & 33.2 & 1.3 & -8 & 55 \\
\hline & Winter & 4552 & 1.5 & 1.0 & 0.30 & -0.55 & 11.5 & 1.6 & -24 & 65 \\
\hline & Spring & 4708 & 1.8 & 1.4 & 0.50 & -0.48 & 14.5 & 1.4 & -19 & 54 \\
\hline & Summer & 4634 & 1.8 & 1.7 & 0.60 & -0.08 & 52.1 & 1.2 & 7 & 47 \\
\hline & Autumn & 4497 & 1.6 & 1.5 & 0.58 & -0.07 & 55.0 & 1.2 & 5 & 56 \\
\hline \multirow{5}{*}{$\begin{array}{l}\text { Nitrate daily } \\
\text { ( } 28 \text { stations) }\end{array}$} & Annual & 9087 & 2.0 & 1.0 & 0.58 & -1.01 & -9.4 & 2.3 & -86 & 112 \\
\hline & Winter & 2227 & 2.7 & 1.5 & 0.60 & -1.17 & 22.0 & 3.1 & -67 & 99 \\
\hline & Spring & 2299 & 2.3 & 1.1 & 0.56 & -1.16 & -6.9 & 2.6 & -76 & 103 \\
\hline & Summer & 2288 & 1.2 & 0.4 & 0.29 & -0.84 & -54.5 & 1.3 & -119 & 132 \\
\hline & Autumn & 2273 & 1.8 & 0.9 & 0.53 & -0.87 & 2.5 & 2.0 & -83 & 114 \\
\hline \multirow{5}{*}{$\begin{array}{l}\text { Ammonium daily } \\
\text { (16 stations) }\end{array}$} & Annual & 5067 & 1.2 & 0.8 & 0.62 & -0.44 & 32.5 & 1.2 & -30 & 71 \\
\hline & Winter & 1263 & 1.4 & 0.8 & 0.70 & -0.68 & 28.8 & 1.5 & -40 & 80 \\
\hline & Spring & 1333 & 1.5 & 0.9 & 0.62 & -0.60 & 21.7 & 1.3 & -37 & 72 \\
\hline & Summer & 1239 & 1.0 & 0.7 & 0.48 & -0.25 & 38.2 & 0.8 & -22 & 62 \\
\hline & Autumn & 1232 & 1.0 & 0.8 & 0.63 & -0.21 & 42.2 & 0.9 & -23 & 70 \\
\hline \multirow{5}{*}{$\begin{array}{l}\text { Chloride daily } \\
\text { (6 stations) }\end{array}$} & Annual & 1564 & 0.3 & 0.3 & 0.45 & 0.06 & 433.2 & 0.5 & 53 & 108 \\
\hline & Winter & 376 & 0.4 & 0.3 & 0.42 & -0.05 & 313.8 & 0.6 & 17 & 99 \\
\hline & Spring & 409 & 0.3 & 0.3 & 0.37 & -0.01 & 298.6 & 0.6 & 41 & 105 \\
\hline & Summer & 400 & 0.1 & 0.3 & 0.51 & 0.15 & 618.3 & 0.3 & 82 & 116 \\
\hline & Autumn & 379 & 0.2 & 0.4 & 0.63 & 0.15 & 500.4 & 0.5 & 71 & 112 \\
\hline \multirow{5}{*}{$\begin{array}{l}\text { Sodium daily } \\
\text { (10 stations) }\end{array}$} & Annual & 3225 & 0.7 & 1.2 & 0.67 & 0.50 & 171.5 & 1.6 & 16 & 77 \\
\hline & Winter & 813 & 0.9 & 1.5 & 0.70 & 0.58 & 175.3 & 1.9 & 18 & 81 \\
\hline & Spring & 840 & 0.6 & 1.1 & 0.64 & 0.46 & 171.2 & 1.6 & 10 & 78 \\
\hline & Summer & 839 & 0.6 & 0.9 & 0.67 & 0.32 & 122.0 & 1.1 & 9 & 71 \\
\hline & Autumn & 833 & 0.7 & 1.4 & 0.65 & 0.64 & 218.1 & 1.8 & 27 & 77 \\
\hline
\end{tabular}

annual and seasonal statistics as well as the average temporal evolution of the model and observations in ground-level EMEP/CREATE stations for SIA components calculated on a daily basis.

The overall annual variability of the modelled sulphate concentrations (Fig. 3) agrees fairly well with measurements $(r=0.49)$, achieving better results in summer $(r=0.60)$ when sulphate concentrations reach maximum levels due to enhanced photochemistry, low air mass renovation and recir- culation at regional scale (Rodríguez et al., 2002; Querol et al., 2009). On average, sulphate levels are underestimated by $18 \%$, less than $\mathrm{PM}_{2.5}$, with winter having the largest bias. In winter, significant underestimations are present at stations in Eastern Europe (E.Eu region), where the mean bias per station ranges from -0.5 to $-2.5 \mu \mathrm{g} \mathrm{m}^{-3}$ (Fig. 3). In contrast, the simulated sulphate exceeds the measurements by $0.3 \mu \mathrm{g} \mathrm{m}^{-3}$ and $0.4 \mu \mathrm{g} \mathrm{m}^{-3}$ at stations in the region of France (S.Fr and C.Fr) and near the Northern Atlantic (N.At), 

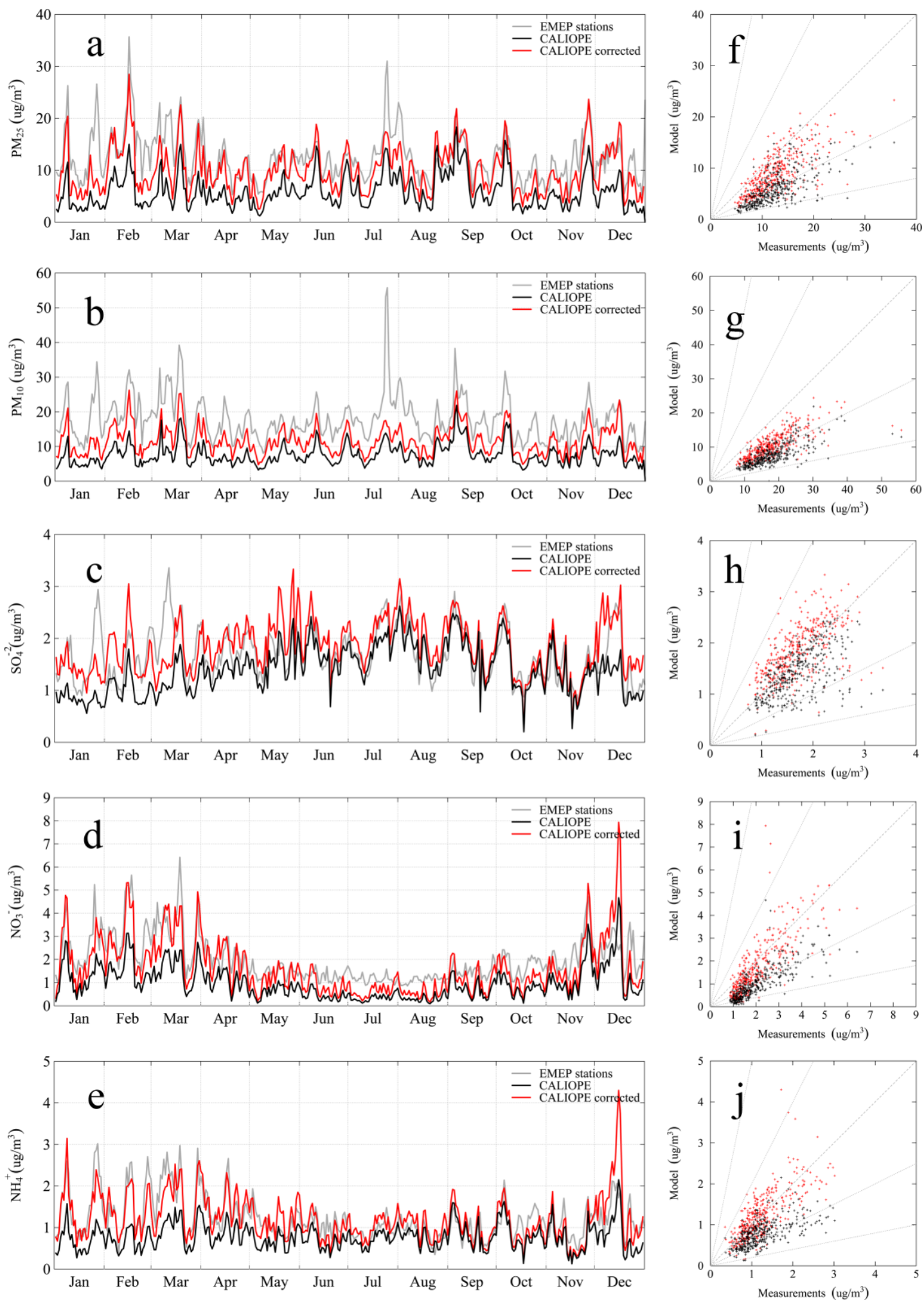

Fig. 2. Modelled (black lines), corrected-modelled (red lines) and measured (grey lines) time series (right) and scatter plots (left) of daily mean concentrations for $\mathrm{PM}_{2.5}, \mathrm{PM}_{10}$, sulphate $\left(\mathrm{SO}_{4}^{-2}\right)$, nitrate $\left(\mathrm{NO}_{3}^{-}\right)$and ammonium $\left(\mathrm{NH}_{4}^{+}\right)$at the EMEP/CREATE stations, respectively. The scatter plots include the 1:1,1:2, 2:1, 1:5 and 5:1 reference lines. Correction factors of the Table 3 are applied to sulphate, nitrate, ammonium and EC + OC in the corrected-modelled series. 
DJF
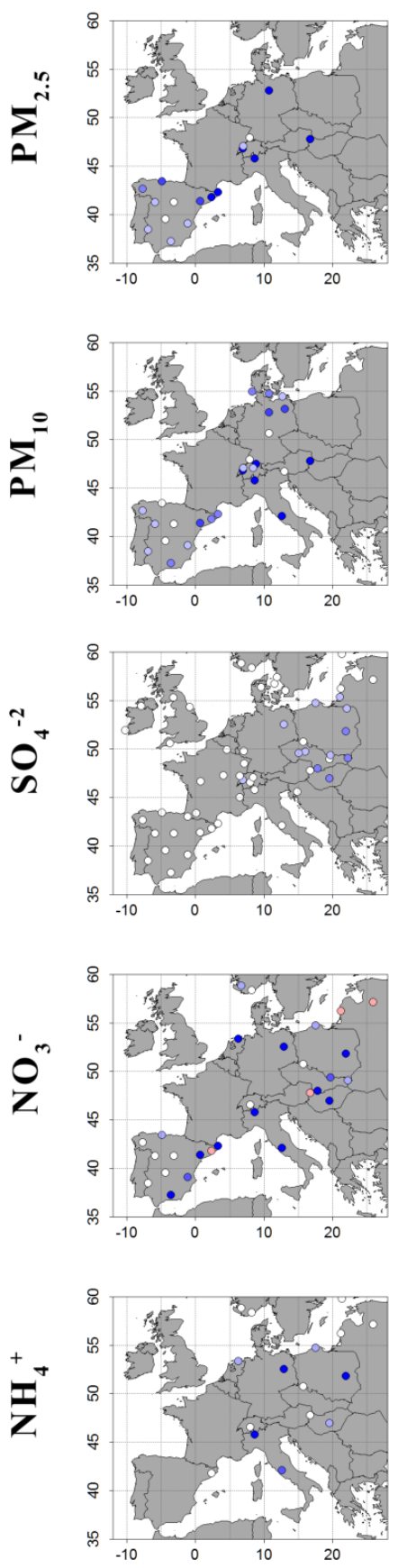

JJA
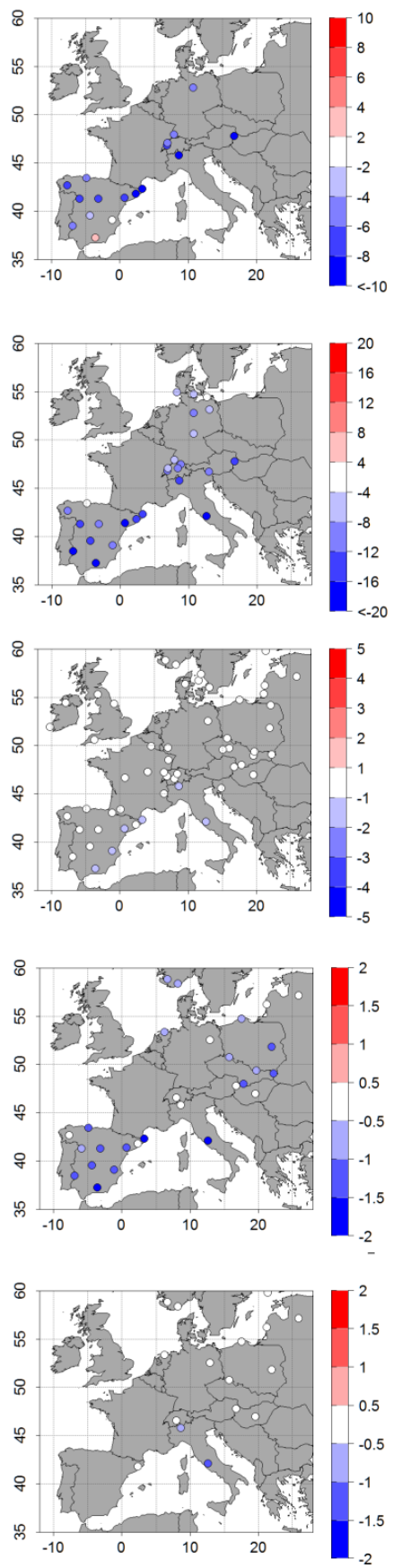

DJF
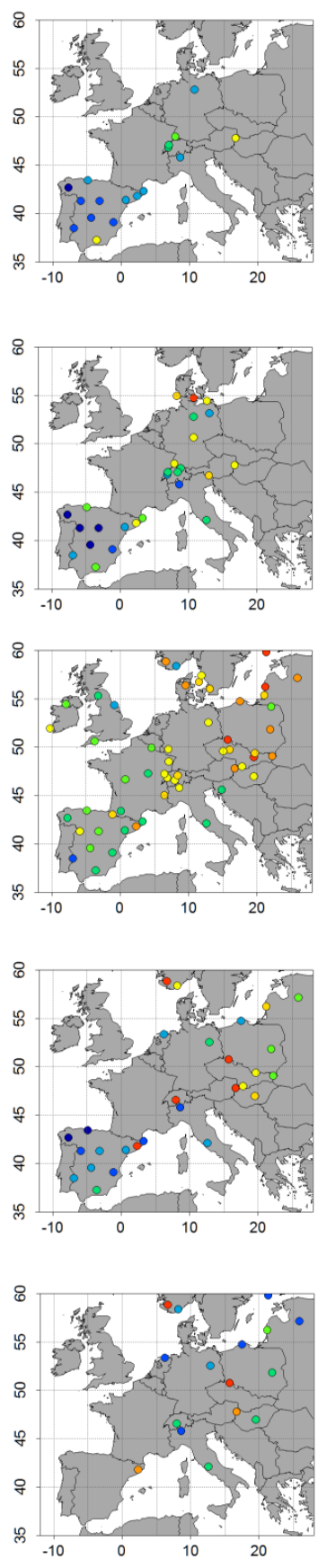

JJA
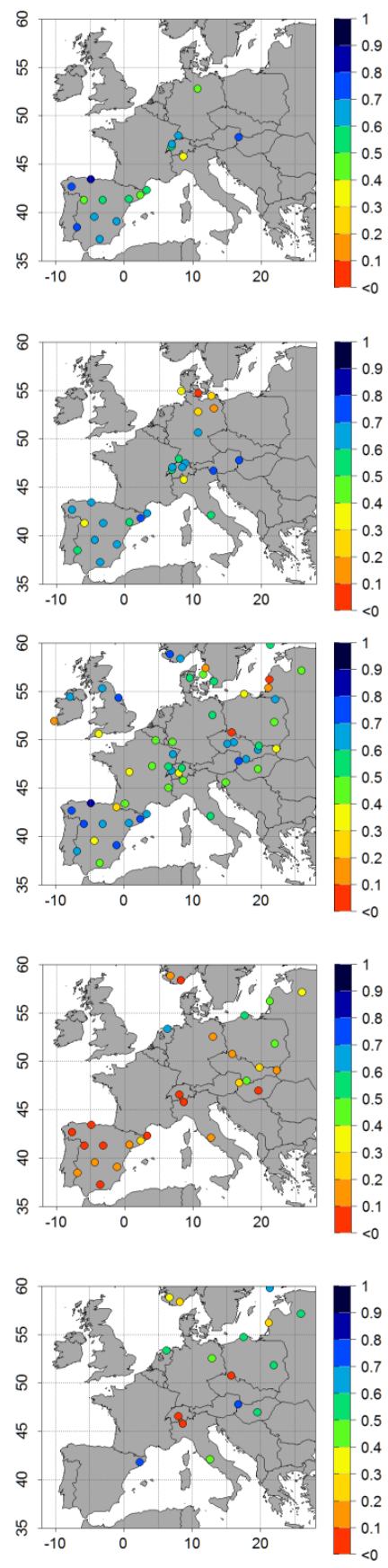

Fig. 3. Spatial distribution of mean bias (left panels; in $\mu \mathrm{g} \mathrm{m}^{-3}$ ) and correlation coefficient (right panels) at all stations for $\mathrm{PM}_{2.5}, \mathrm{PM}_{10}$, sulphate $\left(\mathrm{SO}_{4}^{-2}\right)$, nitrate $\left(\mathrm{NO}_{3}^{-}\right)$and ammonium $\left(\mathrm{NH}_{4}^{+}\right)$. The four columns represent the winter and summer seasons for 2004, respectively, for each parameter.

respectively (Fig. 3). The highest correlations are found in the Iberian Peninsula and the Western Mediterranean Basin, ranging between 0.48 and 0.81 (Fig. 3). Pay et al. (2010) found a positive mean bias for $\mathrm{SO}_{2}$ which suggests that $\mathrm{SO}_{4}^{2-}$ formation in the model is often limited by oxidant availability and not always by $\mathrm{SO}_{2}$ availability. Winter underestima- tion of sulpahte is a common issue in most European models representing a direct couplet of sulfur chemistry with photochemistry and has been previously detected with CMAQv4.5 over Europe (Matthias, 2008). This feature may be explained by a lack of model calculated oxidants or missing reactions (Kasibhatla et al., 1997). 

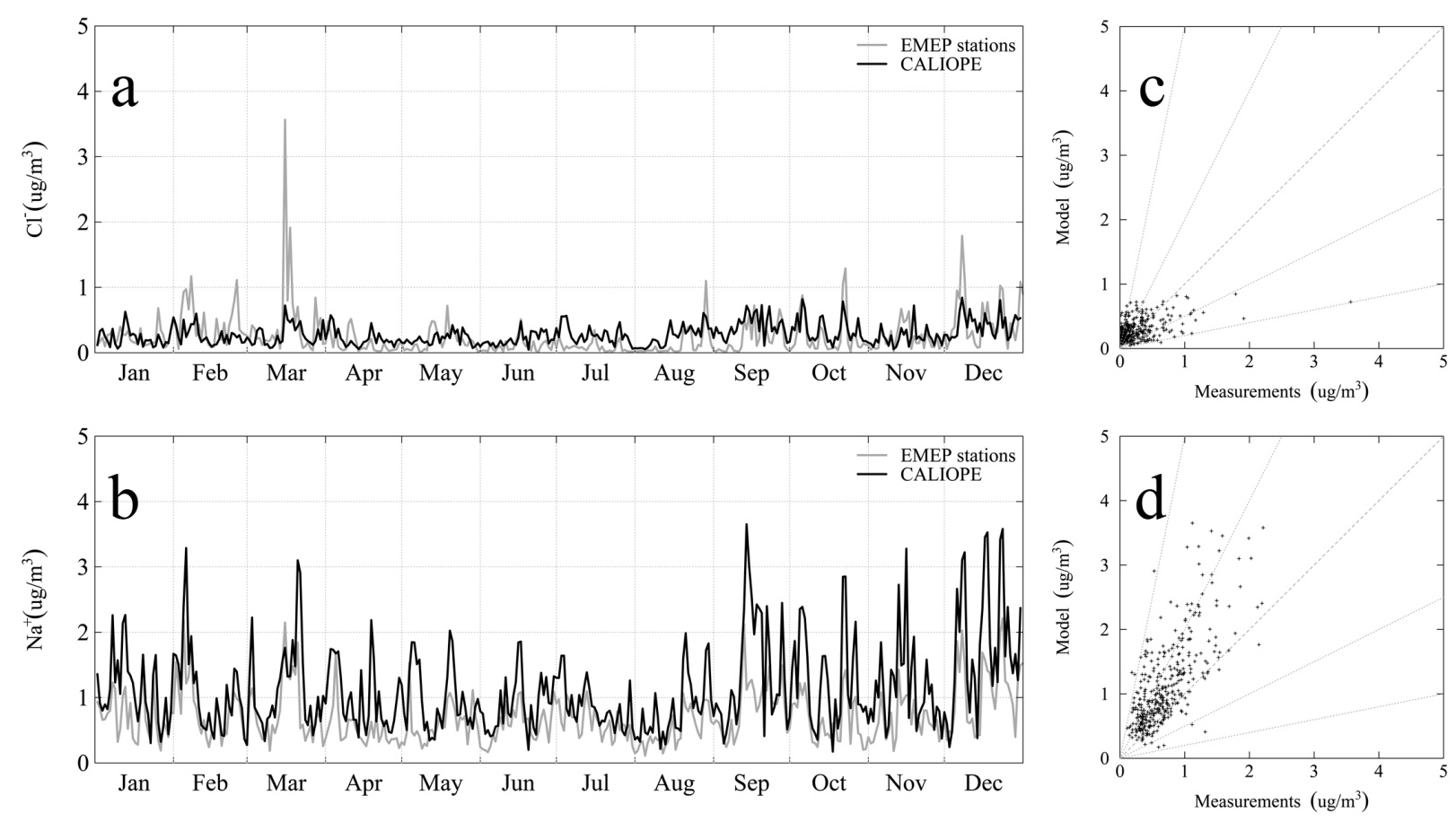

Fig. 4. Modelled (black lines) and measured (grey lines) time series (left) and scatter plots (right) of daily mean concentrations for sea salt chemical species (i.e. chlorine and sodium), at the EMEP/CREATE stations, respectively. The scatter plots include the 1:1, 1:2, 2:1, 1:5 and $5: 1$ reference lines.

On average, modelled nitrate concentrations reproduce the daily variability of the observations through the year $(r=$ 0.58 ), presenting higher concentrations in winter and lower levels in summer due to its thermal instability (Querol et al., 2009). Nitrate formation is limited by the availability of nitric acid over land. The underestimation of nitrate is around $50 \%$, peaking in winter and spring $\left(\mathrm{MB}=-1.2 \mu \mathrm{g} \mathrm{m}^{-3}\right)$ and may be partly attributed to an underestimation of $\mathrm{NO}_{2}$ as outlined and discussed in Pay et al. (2010). The largest underestimations are located over Eastern Iberian PeninsulaWestern Mediterranean (E.IP-W.Med; except at Montseny station) and the Central Mediterranean (C.Med) area with a $\mathrm{MB}$ of $-1.8 \mu \mathrm{g} \mathrm{m}^{-3}$ and Eastern Europe (E.Eu region, except at Illmitz and Sniezka stations) with MB of $-1.5 \mu \mathrm{g} \mathrm{m}^{-3}$ (Fig. 3). As in the case of sulphate, the model presents the best correlation coefficients over the Western Iberian Peninsula ranging from 0.40 to 0.65 (Fig. 3), and a MB below $1 \mu \mathrm{g} \mathrm{m}^{-3}$. In contrast to calcium- and sodiumnitrate, ammonium-nitrate mostly occurs in $\mathrm{PM}_{2.5}$, whereas calcium- and/or sodium-nitrate mostly occur in the coarse $\mathrm{PM}_{2.5-10}$ mode which are known to be significant in Spain from mid-spring to mid-autumn (Rodríguez et al., 2002; Querol et al., 2004, 2009). The fact that CMAQv.4.5 (AERO4) does not consider the formation of coarse calciumand/or sodium-nitrate; it could be related with the underestimations observed in Eastern Spain, particularly in summer (Fig. 3). Moreover, correlations between the simulated and the observed values are rather low in summer in Spain (Fig. 3).

In air masses with a continental signature, nitrate and sulphate are associated with ammonium (Schaap et al., 2004; Querol et al., 2009). Atmospheric ammonia is first neutralized by sulphuric acid to form ammonium sulphate. Remaining ammonia may then combine with nitric acid to form ammonium nitrate (Seinfeld and Pandis, 1998). $94 \%$ of $\mathrm{NH}_{3}$ total emissions are attributed to agriculture and livestock (EMEP, 2007). Livestock sources vary during the year since volatilization of $\mathrm{NH}_{3}$ from the animal waste is a function of temperature (Gilliland et al, 2003). Seasonality in $\mathrm{NH}_{3}$ emission is expected since field application of fertilizers occurs during specific seasons (Asman, 2001). In the CALIOPE system over Europe, annual emissions of $\mathrm{NH}_{3}$ are derived from the 2004 annual EMEP emission database (EMEP, 2007). However, detailed agricultural registers are not generally available in many countries (e.g. Menut and Bessagnet, 2010). The evaluation of ammonium shows that the annual trend is correctly reproduced $(r=0.62$, see Table 1, Figs. 2e and 3) and it is underestimated by $37 \%$, with the highest bias occurring in winter $\left(\mathrm{MB}=-0.68 \mu \mathrm{g} \mathrm{m}^{-3}\right)$.

For sea salt, the modelling system reproduces the daily variability of sodium and chloride with correlations of 0.67 and 0.45 , respectively (Table 1 and Fig. 4). It should be noted that the results are strongly biased towards measurements obtained in northern Europe, since 9 out of 11 stations 
are located there (see Appendix A1). There are 4 coastal stations where the model simulates slightly higher chloride and sodium concentrations than those measured while at continental areas sea salt tends to be underestimated. Correlation for sodium is higher than for chloride since sodium is considered as inert in the atmosphere. One source of uncertainty in AERO4 is the consideration of coarse mode aerosols as dry and inert. This approach does not allow for several aerosol processes, such as the replacement of chloride by nitrate in mixed marine/urban air masses (Kelly et al., 2010) especially intense in summer when nitric acid is released by the thermal instability of ammonium nitrate (Querol et al., 2004). Moreover, degassing of $\mathrm{Cl}^{-}$is not implemented in the model, and heterogeneous reactions are not taken into account. The coarse mode in the AERO4 module in CMAQv4.5 is implemented in a non-interactive way. That is, fine particles do not coagulate with coarse particles, nor do coarse particles coagulate with each other.

Both OC and EC can contribute significantly to $\mathrm{PM}_{2.5}$ and $\mathrm{PM}_{10}$ in urban and kerb sites, and their mass fraction might be higher than the sum of the inorganic components (Putaud et al., 2004). Unfortunately, a detailed investigation of the organic aerosol cannot be done for the present study since there are only very few measurements available that cover a longer time. Therefore OC and EC could only be evaluated at three EMEP/CREATE stations: Birkenes (NO0001), Melpitz (DE0044) and Montseny (ES1778) in 2004 on an annual basis. The results of the carbonaceous aerosol are far from being representative and currently subject to reevaluation by the EUSAAR project. The observed values are approximately a factor of 4 higher than the modelled values. This factor is higher than that obtained by Matthias (2008) at Birkenes in 2001 (factor of 3) partly because carbonaceous particles from biomass burning emissions were taken into account in the aforementioned study. There are other studies that demonstrate that SOA are underestimated by current models by a factor of 6 (Volkamer et al., 2006). The large uncertainties are associated with (1) probable underestimation of primary carbonaceous emission (Cooke and Wilson, 1996; Bond et al., 2004; Tsyro et al., 2007; Monsk et al., 2009) and (2) the state-of-the-science concerning SOA formation pathways (Eder and Yu, 2006; Edney et al., 2007; Appel et al., 2008).

From all anthropogenic emissions used in CALIOPE primary traffic emissions provide the highest contribution of OC and EC ( $80 \%$ of $\mathrm{PM}_{2.5}$ ), followed by combustion in energy and transformation industries $\left(60 \%\right.$ of $\left.\mathrm{PM}_{2.5}\right)$. Additionally, the absence of some natural PM sources (such as wildfire emissions) and primary biogenic emissions (such as pollen, bacteria, fungal and fern spores, fragments of animals and plants, viruses, etc.) contributes to OC underestimation. Wildfire emissions during 2004 were important in southern Europe during summer (European Commission, 2005). Additionally, the traditional 2-product SOA model adopted by CMAQv4.5 (Binkowski and Roselle, 2003) does not include
SOA formation from isoprene and sesquiterpenes. The absence of the isoprene-SOA route on SOA may impact significantly in southern Europe during summer where the predominant vegetation types favour isoprene as the main biogenic volatile organic compounds (VOC; Keenan et al., 2009).

As a summary, the modelling system reproduces reasonably well the daily variability of the main aerosol components in Europe. Their concentrations are in most cases strongly underestimated. The most important underestimations are observed for total carbonaceous material (i.e. OC and EC). The total amount of SIA is on average underestimated by $18-50 \%$. SSA is underestimated inland and overestimated at coastal sites of northern Europe.

\subsection{Aerosol optical depth}

The evaluation of AOD is particularly useful for evaluating the capabilities of the modelling system to reproduce European regional transport and the long-range transport of desert dust from North Africa.

The modelling system is quantitatively compared against direct-sun AOD measurements (AOD) and the AOD mode products from the SDA retrieval ( $\mathrm{AOD}_{\text {fine }}$ and $\left.\mathrm{AOD}_{\text {coarse }}\right)$. Modelled $\mathrm{AOD}_{\text {fine }}$ includes ammonium, sulphate, nitrate, SSA, OC, EC, unspeciated fine fraction from CMAQ and desert dust from BSC-DREAM8b. Modelled AOD coarse $_{\text {is }}$ the sum of the super-micron fraction of desert dust from BSC-DREAM8b and SSA and unspeciated coarse fraction from CMAQ. Table 2 and Fig. 5 show the annual and seasonal statistics, and the temporal evolution of model and AERONET measurements for $\mathrm{AOD}, \mathrm{AOD}_{\text {fine }}$ and $\mathrm{AOD}_{\text {coarse }}$ calculated on an hourly and daily basis.

The model reproduces the AOD hourly and daily variability with average correlations of 0.51 and 0.56 , respectively (Table 2, Figs. 5a and 6) and underestimates the hourly and daily AOD by 41 and $38 \%$, respectively (Table 2, Figs. 5a and 6).

If we take a closer look to the desert dust component and its role on the model skills, its influence is remarkable. When considering only CMAQ outputs the AOD underestimation rises up to $61 \%$ for hourly values and $58 \%$ for daily values and the annual correlation decreases to 0.39 for the hourly values and to 0.40 for daily values. The differences between CMAQ-alone and CMAQ+BSC-DREAM8b are larger in the Iberian Peninsula and Mediterranean sites due to the proximity to the African continent. Correlations remarkably improve from 0.16 to $0.59,0.39$ to $0.58,0.31$ to 0.49 and 0.05 to 0.50 , for the Western Iberian Peninsula, Eastern Iberian Peninsula-Western Mediterranean, Central Mediterranean and Eastern Mediterranean, respectively for hourly values. Averaging over the entire study region, desert dust contributions represent about $35 \%$ of the AOD and over the Iberian Peninsula and the Mediterranean about $51 \%$ on average. These results are consistent with the aerosol characterization presented in Basart et al. (2009). 
Table 2. Seasonal and annual statistics obtained with CALIOPE over Europe for 2004 at the AERONET stations for AOD, AOD fine $_{\text {and }}$

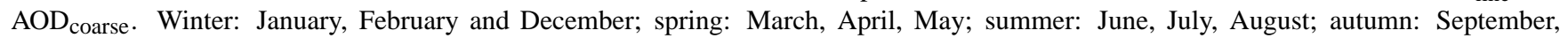
October, November. The number of data points indicates the number of pair measurement-model used to compute the statistics. The calculated statistics are: measured mean for available data, modelled mean for the whole year, correlation coefficient $(r)$, mean bias (MB), mean normalize bias error (MNBE), root mean square error (RMSE), mean fractional bias (MFB) and mean fractional error (MFE).

\begin{tabular}{|c|c|c|c|c|c|c|c|c|c|c|}
\hline & & $\begin{array}{r}\text { Data } \\
\text { Points }\end{array}$ & $\begin{array}{l}\text { Obs. } \\
\text { Mean }\end{array}$ & $\begin{array}{l}\text { Mod. } \\
\text { Mean }\end{array}$ & $r$ & MB & $\begin{array}{l}\text { MNBE } \\
(\%)\end{array}$ & RMSE & $\begin{array}{r}\text { MFB } \\
(\%)\end{array}$ & $\begin{array}{r}\mathrm{MFE} \\
(\%)\end{array}$ \\
\hline \multirow{5}{*}{$\begin{array}{l}\text { AOD hourly } \\
\text { (35 stations) }\end{array}$} & Annual & 34925 & 0.18 & 0.10 & 0.51 & $-0,07$ & -31.0 & 0.15 & -53 & 66 \\
\hline & Winter & 4175 & 0.12 & 0.07 & 0.36 & $-0,05$ & -23.1 & 0.13 & -49 & 69 \\
\hline & Spring & 9099 & 0.19 & 0.11 & 0.49 & $-0,07$ & -32.3 & 0.16 & -57 & 70 \\
\hline & Summer & 14249 & 0.19 & 0.11 & 0.49 & $-0,08$ & -34.8 & 0.16 & -56 & 66 \\
\hline & Autumn & 7402 & 0.16 & 0.10 & 0.62 & $-0,06$ & -26.6 & 0.13 & -45 & 58 \\
\hline \multirow{5}{*}{$\begin{array}{l}\mathrm{AOD}_{\text {fine }} \text { hourly } \\
\text { (16 stations) }\end{array}$} & Annual & 15914 & 0.22 & 0.10 & 0.52 & -0.13 & -48.7 & 0.19 & -75 & 80 \\
\hline & Winter & 1459 & 0.14 & 0.06 & 0.42 & $-0,09$ & -45.9 & 0.16 & -78 & 87 \\
\hline & Spring & 3828 & 0.24 & 0.11 & 0.55 & $-0,13$ & -49.5 & 0.19 & -77 & 82 \\
\hline & Summer & 7250 & 0.24 & 0.10 & 0.45 & $-0,14$ & -50.7 & 0.20 & -77 & 80 \\
\hline & Autumn & 3377 & 0.21 & 0.10 & 0.62 & $-0,12$ & -44.9 & 0.19 & -69 & 74 \\
\hline \multirow{5}{*}{$\begin{array}{l}\text { AOD coarse hourly } \\
\text { (16 stations) }\end{array}$} & Annual & 15914 & 0.06 & 0.02 & 0.63 & -0.04 & -72.9 & 0.07 & -134 & 139 \\
\hline & Winter & 1459 & 0.05 & 0.02 & 0.25 & -0.04 & -69.4 & 0.07 & -133 & 141 \\
\hline & Spring & 3828 & 0.07 & 0.02 & 0.58 & -0.04 & -73.3 & 0.09 & -137 & 142 \\
\hline & Summer & 7250 & 0.05 & 0.02 & 0.70 & -0.03 & -73.1 & 0.06 & -135 & 139 \\
\hline & Autumn & 3377 & 0.06 & 0.02 & 0.71 & -0.04 & -73.6 & 0.07 & -130 & 133 \\
\hline \multirow{5}{*}{$\begin{array}{l}\text { AOD daily } \\
\text { (35 stations) }\end{array}$} & Annual & 4920 & 0.18 & 0.11 & 0.56 & -0.07 & -28.2 & 0.14 & -47 & 60 \\
\hline & Winter & 792 & 0.12 & 0.07 & 0.41 & -0.05 & -23.6 & 0.12 & -46 & 63 \\
\hline & Spring & 1267 & 0.19 & 0.12 & 0.52 & -0.07 & -28.8 & 0.15 & -51 & 64 \\
\hline & Summer & 1689 & 0.20 & 0.12 & 0.55 & -0.08 & -33.3 & 0.15 & -51 & 60 \\
\hline & Autumn & 1172 & 0.16 & 0.11 & 0.67 & -0.06 & -24.5 & 0.12 & -39 & 52 \\
\hline \multirow{5}{*}{$\begin{array}{l}\text { AOD }_{\text {fine daily }} \\
\text { (16 stations) }\end{array}$} & Annual & 2318 & 0.22 & 0.10 & 0.59 & -0.12 & -45.1 & 0.18 & -69 & 74 \\
\hline & Winter & 304 & 0.14 & 0.06 & 0.45 & -0.08 & -43.8 & 0.14 & -71 & 80 \\
\hline & Spring & 556 & 0.25 & 0.12 & 0.58 & -0.13 & -45.9 & 0.18 & -70 & 75 \\
\hline & Summer & 919 & 0.24 & 0.10 & 0.53 & -0.14 & -47.5 & 0.19 & -70 & 73 \\
\hline & Autumn & 539 & 0.21 & 0.10 & 0.68 & -0.11 & -41.0 & 0.19 & -62 & 69 \\
\hline \multirow{5}{*}{$\begin{array}{l}\text { AOD }_{\text {coarse daily }} \\
\text { (16 stations) }\end{array}$} & Annual & 2318 & 0.06 & 0.02 & 0.70 & -0.04 & -74.6 & 0.07 & -134 & -138 \\
\hline & Winter & 304 & 0.05 & 0.01 & 0.24 & -0.04 & -71.0 & 0.07 & -132 & 138 \\
\hline & Spring & 556 & 0.07 & 0.02 & 0.65 & -0.05 & -72.7 & 0.08 & -134 & 138 \\
\hline & Summer & 919 & 0.05 & 0.02 & 0.77 & -0.03 & -76.9 & 0.06 & -139 & 141 \\
\hline & Autumn & 539 & 0.06 & 0.02 & 0.80 & -0.04 & -74.6 & 0.06 & -130 & 131 \\
\hline
\end{tabular}

Because the evaluation of the aerosol model performance is hampered by the lack of routine data above the surface, satellite observations offer new opportunities for model evaluation. In Fig. 7, the seasonal averages for 2004 of the collection C005 AOD data (cloud free) at $550 \mathrm{~nm}$ from MODIS/Aqua sensor (Levy et al., 2003; Remer et al., 2005) are qualitatively compared with the modelled aerosol fields. Additionally, superimposed to MODIS values, the AERONET seasonal mean values are included showing moderate differences between both observational datasets. Among other causes, this is partly because the satellite product is obtained from 2 images per day in contrast to more frequent AERONET measurements during the day.
In general, the CALIOPE system reproduces the main seasonal AOD patterns observed in MODIS despite the important underestimations at hot spots located in Northern Italy, Eastern and North-western Europe as shown in the comparison with AERONET data. The dust transport from North Africa is well captured with maximum AOD values in the Eastern Mediterranean in spring shifting to the Central and Western Mediterranean in summer.

The aerosol fields obtained with CALIOPE are similar to those shown in other European modelling studies (e.g. POLYPHEMUS; Tombette et al., 2008; CHIMERE, Péré et al., 2010). In another study with CMAQ (Matthias, 2008), the modelled AOD was 20 to $70 \%$ lower than 

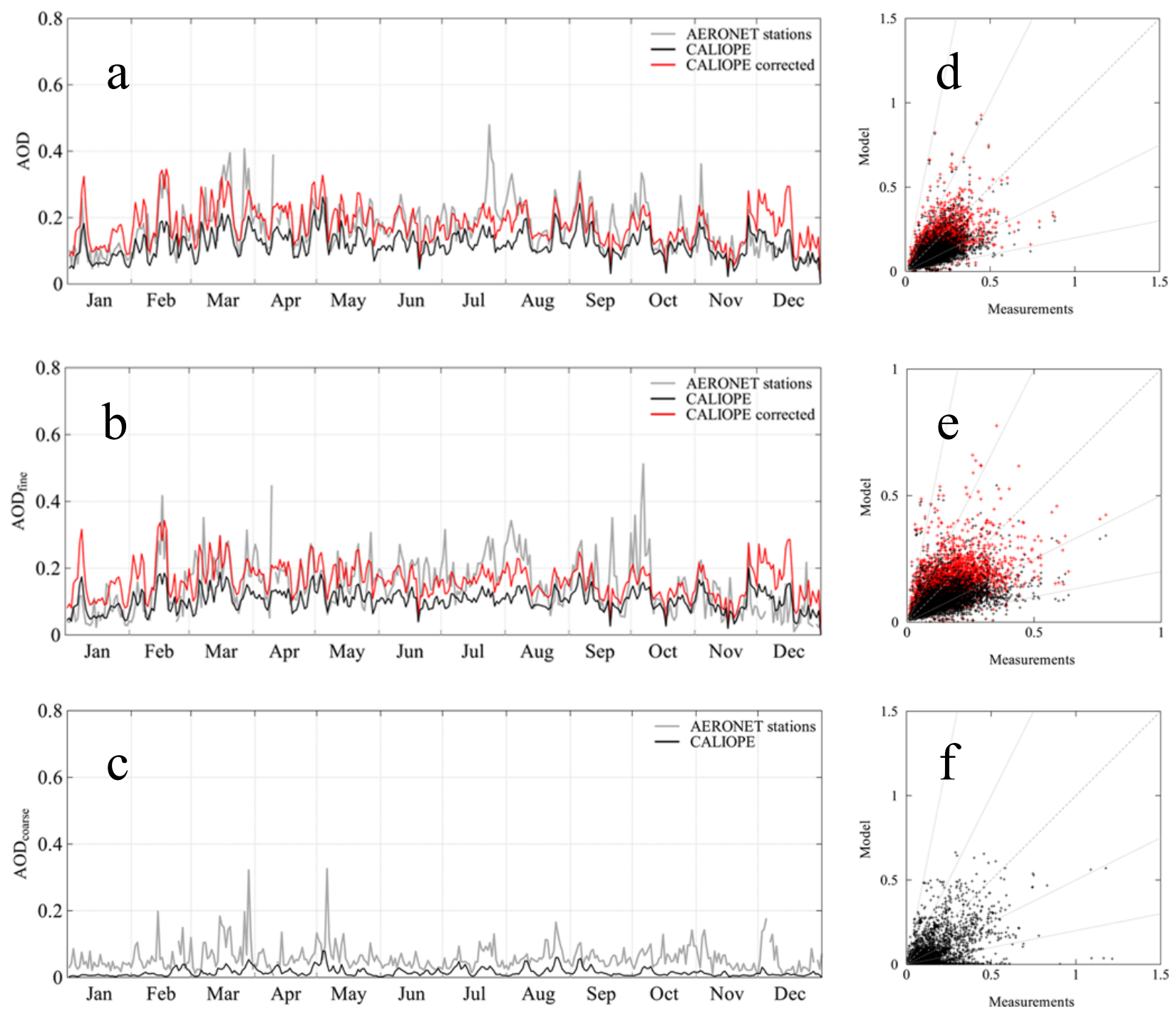

Fig. 5. Modelled (black lines), corrected-modelled (red lines) and measured (grey lines) mean daily time series (right) and scatter plots of mean hourly values (left) for AOD, AOD $_{\text {fine }}$ and AOD $_{\text {coarse }}$ at the AERONET stations. The scatter plots include the 1:1, 1:2, 2:1, 1:5 and 5:1 reference lines. Correction factors of Table 3 are applied to sulphate, nitrate and ammonium and EC + OC in the corrected-modelled series.

AERONET observations. In contrast to our results, the best scores in this study were achieved in northern sites where desert dust contributions are smaller, which again highlights the importance of desert dust in southern latitudes. The evaluation of the POLYPHEMUS system (Tombette et al., 2008), which also did not consider desert dust, against 19 AERONET stations underestimated the hourly AOD average from 0.02 to 0.07 and correlations ranged from 0.40 to 0.87 obtaining the best results in the northern European sites. In the evaluation of the CHIMERE model against 13 AERONET stations presented in Péré et al. (2010), correlations lied within the range of $0.50-0.74$. The values obtained in the present work lie within the range of these studies with correlations of $0.40-0.72$ depending on the region.

We take a closer look now at the fine and coarse components of the AOD. The annual and seasonal statistics for
$\mathrm{AOD}_{\text {fine }}$ and $\mathrm{AOD}_{\text {coarse }}$ are presented in Table 2 and Fig. 6 and the temporal series are shown in Fig. $5 \mathrm{~b}$ and c, respectively. Desert dust contributions to $\mathrm{AOD}_{\text {fine }}$ and $\mathrm{AOD}_{\text {coarse }}$ are on average $22 \%$ and $88 \%$, respectively. The largest discrepancies between model and data are associated to $\mathrm{AOD}_{\text {fine }}$ $(\mathrm{MB}=-0.13$ and $\mathrm{RMSE}=0.19$, Table 2$)$, although the hourly variability is reasonably well captured $(r=0.52$, see Figs. $5 \mathrm{~b}$ and 6). The best scores are found at SMHI site in the Nordic region $(r=0.70, \mathrm{RMSE}=0.04$ and $\mathrm{MB}=-0.03)$ where no desert dust is present in the fine mode AOD and where the frequent background situation is associated with low values. The largest error in $\mathrm{AOD}_{\text {fine }}$ is found for Northern Italy (RMSE $=0.29$ and $\mathrm{MB}=-0.20$ ). The correlation remains moderately high though $(\sim 0.52)$ indicating that the modelling system is able to reproduce reasonably well the background AOD and the occurrence of enhanced (or peak) 

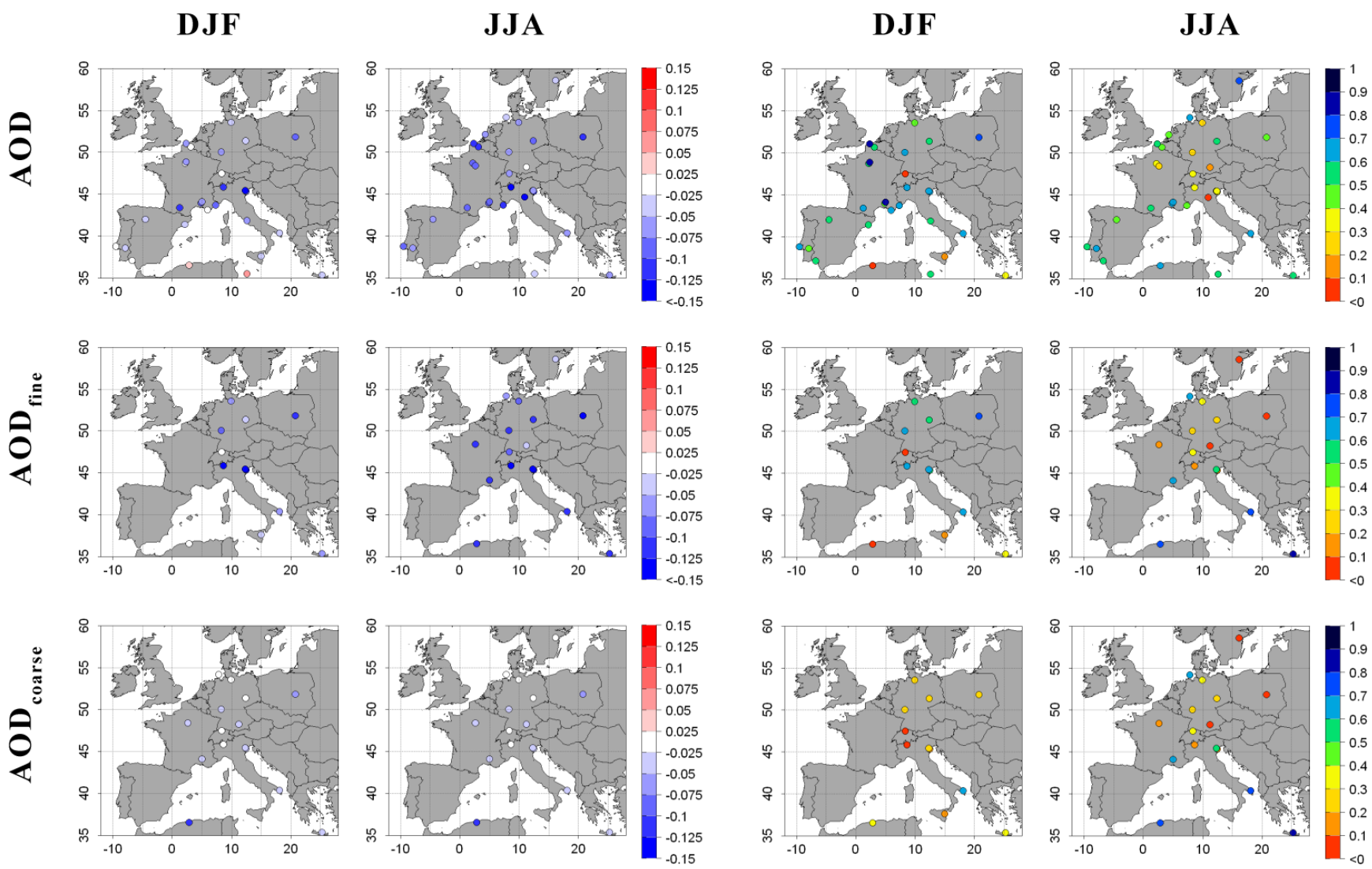

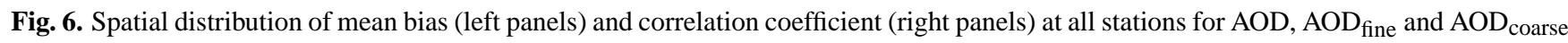
in hourly basis. The four columns represent the winter and summer seasons for 2004 for each parameter.

concentrations (or episodes). Northern Italy includes one of the most polluted regions in Europe, the Po Valley (Mélin and Zibordi, 2005) and the model indicates almost no contribution from dust (less than $4 \%$ ) in agreement with Gobbi et al. (2007). In this area, the air stagnation in a mountainsurrounded valley favours photochemical reactions that produce SIA and fine mode growth (Gobbi et al., 2007) together with frequent humid conditions in winter which favours nucleation and growth of aerosols.

The daily variability of $\mathrm{AOD}_{\text {coarse }}$ is well reproduced $(r=0.63$, see Fig. 5c). The best scores are found in the Mediterranean Basin $(0.6<r<0.8, \mathrm{RMSE}<0.09$ and $\mathrm{MB} \sim-0.04$, on average in hourly mean values for the entire Basin) particularly in summertime coinciding with the maximum $\mathrm{AOD}_{\text {coarse }}$ values and maximum activity in the desert dust sources (Middelton and Goudie, 2001). The largest discrepancies are found in Nordic countries $(r=0.06$, $\mathrm{RMSE}=0.03$ and $\mathrm{MB}=-0.02)$ and Eastern Europe $(r=$ $0.18, \mathrm{RMSE}=0.10$ and $\mathrm{MB}=-0.06$ ). In general, the highest $\mathrm{AOD}_{\text {coarse }}$ values are linked to the presence of desert dust. However, some coarse events of coarse particles in NorthWestern and Eastern Europe are not captured by the modelling system (not shown here). Theses episodes may be linked to the occurrence of the coarse sodium and calcium nitrate because high levels of sulphate neutralize ammonium (Querol et al., 2009).

The ESCOMPTE experiment (Mallet et al., 2003), which investigated the microphysical and optical properties of aerosols around Marseille in the summer 2001, showed that $90 \%$ of the light extinction was due to anthropogenic aerosol and only $10 \%$ was due to natural aerosol (SSA and desert dust). $44 \%$ of the anthropogenic extinction was due to ammonium sulphate, followed by $20 \%$ from EC and $21 \%$ from organic matter. Nitrate aerosol had a weak contribution of about 5\%. In our study, the Western Mediterranean sites (i.e. Avignon, Carpentras, Toulon and Villefrange) in summer, show a $28 \%$ contribution of natural aerosol (SSA and desert dust) and a $72 \%$ contribution of anthropogenic aerosol to the extinction. In our model, $54 \%$ of the anthropogenic extinction is due to ammonium sulphate followed by nitrate $(\sim 13 \%)$ and $\mathrm{EC}(\sim 6 \%)$ and $\mathrm{OC}(\sim 9 \%)$. These results reveal a significant underestimation of total carbonaceous material species which can be partly explained by the influence of local emissions and natural sources as indicated in the Sect. 3.2. The uncertainties associated to the emission inventory for black carbon may be an important cause for the discrepancy (Baldasano et al., 2008b). 

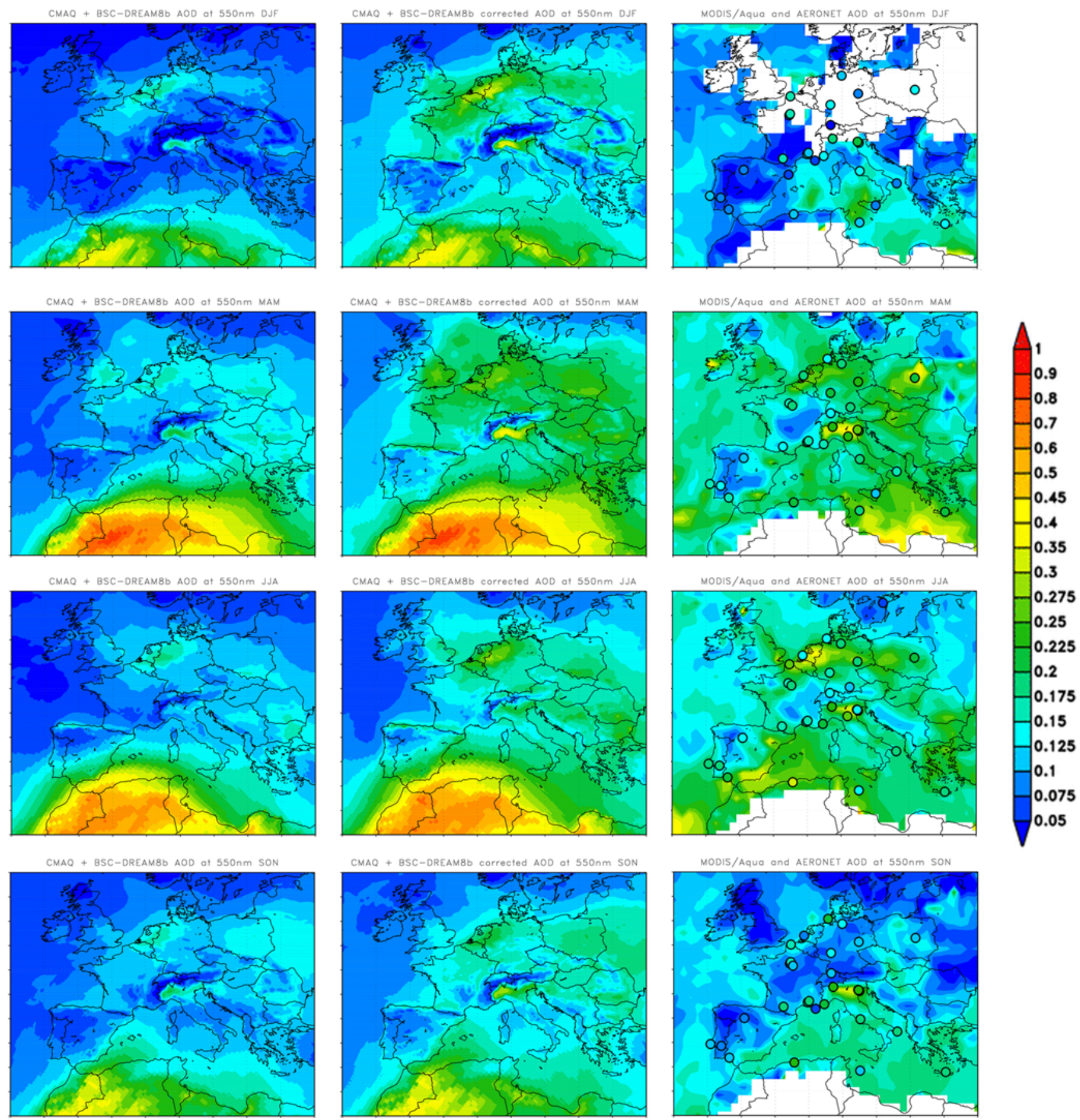

Fig. 7. Seasonal AOD average (from top to bottom) of CMAQ + BSC-DREAM8b without correction factor (left panels), CMAQ + BSCDREAM8b with correction factors of Table 3 for sulphate, nitrate and ammonium and EC + OC (central panels) and MODIS/Aqua AOD (rigth panels) with AERONET seasonal mean values in coloured circles. 
Table 3. Seasonal and annual multiplicative correction factors for SIA (sulphate, nitrate and ammonium) and EC + OC obtained minimizing the weighted sum of the squared difference between the modelled and measured chemical aerosol surface concentrations on a daily basis over Europe for 2004. Winter: January, February and December; spring: March, April, May; summer: June, July, August; autumn: September, October, November.

\begin{tabular}{lcccc}
\hline & Sulphate & Nitrate & Ammonium & OC + EC \\
\hline Winter & 1.7 & 1.7 & 2.0 & 4 \\
Spring & 1.4 & 1.8 & 1.7 & 4 \\
Summer & 1.2 & 1.9 & 1.4 & 4 \\
Autumn & 1.1 & 1.5 & 1.2 & 4 \\
Annual & 1.3 & 1.7 & 1.6 & 4 \\
\hline
\end{tabular}

\section{Aerosol distribution over Europe}

\subsection{Model bias correction}

Several studies have demonstrated the benefit of adjusting site-specific air quality model predictions using observational data to reduce systematic model error (e.g. Hogrefe et al., 2006; Djalalova et al., 2010). Bias-adjustment strategies range from the relatively simple mean bias and multiplicative ratio adjustments used by McKeen et al. (2005) to the more complex Kalman filter techniques (Manders et al., 2009; Kang et al., 2010; Sicardi et al., 2011). In this section we provide an estimation of the spatial and seasonal distribution of the different aerosol components over Europe with our model results including an a posteriori correction. The evaluation consistently reveals a similar degree of underestimation of the fine fraction on both surface levels and columnintegrated values (AOD) and the correction applied is based on the results of the evaluation of the chemical aerosol composition presented in Sect. 2.3.1.

We calculate spatially homogeneous multiplicative correction factors per aerosol species and apply it to the mass concentrations in the model. The main limitation of this method is the application of a spatially homogeneous correction factor for a large region such as Europe. However, as shown in the model evaluation results, the seasonal variability has a stronger impact than the geographical differences in the formation of the secondary atmospheric aerosols. As described below the modelled bulk parameters (PM and AOD levels) significantly improve after correcting the bias of each aerosol species individually.

For carboneous compounds, a spatially homogeneous mean annual multiplicative correction factor of 4 is estimated. For the SIA (i.e. sulphate, nitrate and ammonium) seasonal correction factors are calculated from the modelled and observed mean daily values. We employ a weighted sum of the squared difference between the modelled and observed values. We minimize this sum to identify the magnitude of the aerosol concentration being in optimal agreement with the observations. Table 3 shows the spatially homogeneous multiplicative correction factors obtained for each chemical species. The bias corrected simulation is then evaluated against the bulk PM and AOD observations from EMEP and AERONET (Table 4).

The corrected $\mathrm{PM}_{2.5}$ and $\mathrm{PM}_{10}$ results present a much better agreement with the observations if correction factors are applied (Fig. 2 and Table 4). The annual underestimations are reduced from 53 to $19 \%$ for $\mathrm{PM}_{2.5}$ and from 58 to $35 \%$ for $\mathrm{PM}_{10}$. Correlations increase from 0.47 to 0.61 for $\mathrm{PM}_{2.5}$ and from 0.57 to 0.62 for $\mathrm{PM}_{10}$. MFE and MFB for the corrected $\mathrm{PM}_{2.5}$ fall within the performance goal and the corrected $\mathrm{PM}_{10}$ within the performance criterion proposed by Boylan and Russell (2006). Correlation coefficient RMSE, MFB and MFE of $\mathrm{PM}_{2.5}$ and $\mathrm{PM}_{10}$ with correction factors are significantly better than those obtained in Pay et al. (2010) by applying a factor of 2 to total $\mathrm{PM}_{2.5}$ and $\mathrm{PM}_{10}$.

Underestimations are reduced from 57 to $32 \%$ for the hourly $\mathrm{AOD}_{\text {fine }}$ and from 41 to $13 \%$ for the hourly AOD. Correlation coefficients increase from 0.52 to 0.56 for the hourly $\mathrm{AOD}_{\text {fine }}$ and from 0.51 to 0.56 for the hourly AOD (Table 2 and Figs. 5 and 6). Similar results are obtained for daily AOD and $\mathrm{AOD}_{\text {fine }}$ (see Table 4). Finally, Fig. 7 highlights the closer agreement between the model corrected seasonal AOD distribution and the MODIS/Aqua satellite product in comparison with the uncorrected model estimates. The corrected simulation provides more realistic information for the analysis of the aerosol spatial and temporal patterns over Europe.

\subsection{Spatial and seasonal distribution of PM concentrations and AOD}

Figure 8 depicts the corrected-modelled annual mean of $\mathrm{PM}_{2.5}, \mathrm{PM}_{10}$, AOD and $\mathrm{AOD}_{\text {fine. The highest mean }}$ aerosol concentrations (AOD $>0.3$ and $\mathrm{PM}_{10}>30 \mu \mathrm{g} \mathrm{m}^{-3}$ ) found over the Po Valley and the Benelux region (Belgium, The Netherlands, Luxembourg) are dominated by fine anthropogenic aerosols. A second maximum is found over South-eastern Europe (AOD 0.2) and southern Europe $\left(\mathrm{AOD}>0.2\right.$ and $\left.\mathrm{PM}_{10}>20 \mu \mathrm{g} \mathrm{m}^{-3}\right)$. Aerosol concentrations decrease towards the North and North-western Europe reaching the lowest values in the northern region $(\mathrm{AOD}<0.15)$ in agreement with the modelling study of Schaap et al. (2004). Low values are also found over the major European mountain chains, i.e. the Alps, Massif Central, the Pyrenees and the Carpathians with AOD $<0.1$ and $\mathrm{PM}_{10}<10 \mu \mathrm{g} \mathrm{m}^{-3}$.

We distinguish some common features in the columnintegrated and surface distributions such as the high values over the North of Italy and the Netherlands. There are also significant contrasts as for instance the maritime areas in the North Atlantic region and Eastern Europe. Differences over the North Atlantic region are associated to the relatively low SSA extinction (Dubovik et al., 2002) in comparison 
Table 4. Seasonal and annual statistics obtained with CALIOPE and the seasonal correction factors applied to sulphate, nitrate, ammonium and EC + OC over Europe for 2004 at the EMEP stations for $\mathrm{PM}_{2.5}\left(\right.$ in $\mu \mathrm{g} \mathrm{m}^{-3}$ ) and $\mathrm{PM}_{10}$ (in $\mu \mathrm{g} \mathrm{m}^{-3}$ ) and at the AERONET stations for $\mathrm{AOD}_{\text {fine }}$ and AOD. Winter: January, February and December; spring: March, April, May; summer: June, July, August; autumn: September, October, November. The number of data points indicates the number of pair measurement-model used to compute the statistics. The calculated statistics are: measured mean for available data, modelled mean for the whole year, correlation coefficient ( $r$ ), mean bias (MB), mean normalize bias error (MNBE), root mean square error (RMSE), mean fractional bias (MFB) and mean fractional error (MFE).

\begin{tabular}{|c|c|c|c|c|c|c|c|c|c|c|}
\hline & & $\begin{array}{r}\text { Data } \\
\text { Points }\end{array}$ & $\begin{array}{l}\text { Obs. } \\
\text { Mean }\end{array}$ & $\begin{array}{l}\text { Mod. } \\
\text { Mean }\end{array}$ & $r$ & $\mathrm{MB}$ & $\begin{array}{r}\mathrm{MNBE} \\
(\%)\end{array}$ & RMSE & $\begin{array}{r}\text { MFB } \\
(\%)\end{array}$ & $\begin{array}{c}\mathrm{MFE} \\
(\%)\end{array}$ \\
\hline \multirow{5}{*}{$\begin{array}{l}\mathrm{PM}_{2.5} \text { daily } \\
\text { (17 stations) }\end{array}$} & Annual & 5437 & 12.47 & 10.10 & 0.61 & -2.36 & -6.7 & 8.81 & -22 & 47 \\
\hline & Winter & 1252 & 13.68 & 10.43 & 0.67 & -3.25 & -4.5 & 11.52 & -18 & 54 \\
\hline & Spring & 1344 & 12.28 & 9.84 & 0.59 & -2.43 & -9.8 & 8.30 & -24 & 45 \\
\hline & Summer & 1468 & 12.40 & 10.11 & 0.55 & -2.29 & -15.7 & 7.49 & -28 & 45 \\
\hline & Autumn & 1373 & 11.62 & 10.05 & 0.62 & -1.57 & 4.3 & 7.65 & -19 & 44 \\
\hline \multirow{5}{*}{$\begin{array}{l}\mathrm{PM}_{10} \text { daily } \\
\text { (26 stations) }\end{array}$} & Annual & 8708 & 17.84 & 11.64 & 0.62 & -6.20 & -20.9 & 12.84 & -39 & 54 \\
\hline & Winter & 2075 & 17.95 & 11.82 & 0.65 & -6.13 & -9.5 & 14.04 & -32 & 56 \\
\hline & Spring & 2167 & 17.64 & 11.91 & 0.59 & -5.74 & -22.6 & 11.76 & -39 & 51 \\
\hline & Summer & 2276 & 18.67 & 11.25 & 0.60 & -7.42 & -32.3 & 14.25 & -48 & 56 \\
\hline & Autumn & 2190 & 17.08 & 11.62 & 0.66 & -5.45 & -18.5 & 11.02 & -35 & 52 \\
\hline \multirow{5}{*}{$\begin{array}{l}\text { AOD }_{\text {fine }} \text { hourly } \\
\text { (16 stations) }\end{array}$} & Annual & 15914 & 0.22 & 0.15 & 0.55 & -0.07 & 6.3 & 0.16 & -36 & 6 \\
\hline & Winter & 1459 & 0.14 & 0.10 & 0.56 & -0.05 & 15.5 & 0.13 & -26 & 55 \\
\hline & Spring & 3828 & 0.24 & 0.18 & 0.57 & -0.06 & 2.3 & 0.16 & -32 & 50 \\
\hline & Summer & 7250 & 0.24 & 0.15 & 0.48 & -0.08 & 1.6 & 0.16 & -35 & 50 \\
\hline & Autumn & 3377 & 0.21 & 0.14 & 0.66 & -0.08 & 15.2 & 0.16 & -36 & 52 \\
\hline \multirow{5}{*}{$\begin{array}{l}\text { AOD hourly } \\
\text { (35 stations) }\end{array}$} & Annual & 34925 & 0.18 & 0.15 & 0.56 & -0.02 & -16.5 & 0.13 & -12 & 46 \\
\hline & Winter & 4175 & 0.12 & 0.11 & 0.48 & -0.00 & -13.4 & 0.01 & 1 & 49 \\
\hline & Spring & 9099 & 0.19 & 0.18 & 0.55 & -0.01 & -19.7 & 0.14 & -12 & 45 \\
\hline & Summer & 14249 & 0.19 & 0.16 & 0.53 & -0.04 & -18.5 & 0.14 & -16 & 45 \\
\hline & Autumn & 7402 & 0.16 & 0.14 & 0.66 & -0.03 & -10.0 & 0.12 & -13 & 46 \\
\hline \multirow{5}{*}{$\begin{array}{l}\text { AOD }_{\text {fine daily }} \\
\text { (16 stations) }\end{array}$} & Annual & 2318 & 0.22 & 0.16 & 0.61 & -0.07 & -13.3 & 0.15 & -28 & 46 \\
\hline & Winter & 304 & 0.14 & 0.11 & 0.54 & -0.03 & 0.0 & 0.12 & -19 & 48 \\
\hline & Spring & 556 & 0.25 & 0.19 & 0.60 & -0.06 & -11.9 & 0.15 & -25 & 44 \\
\hline & Summer & 919 & 0.24 & 0.16 & 0.56 & -0.08 & 17.1 & 0.16 & -30 & 46 \\
\hline & Autumn & 539 & 0.21 & 0.14 & 0.71 & -0.07 & -16.1 & 0.16 & -31 & 48 \\
\hline \multirow{5}{*}{$\begin{array}{l}\text { AOD daily } \\
\text { (35 stations) }\end{array}$} & Annual & 4920 & 0.18 & 0.14 & 0.60 & -0.04 & -1.9 & 0.12 & -15 & 42 \\
\hline & Winter & 792 & 0.12 & 0.11 & 0.57 & -0.01 & -14.4 & 0.10 & -3 & 43 \\
\hline & Spring & 1267 & 0.19 & 0.17 & 0.55 & -0.02 & -3.1 & 0.12 & -16 & 40 \\
\hline & Summer & 1689 & 0.20 & 0.15 & 0.59 & -0.05 & -7.4 & 0.12 & -20 & 43 \\
\hline & Autumn & 1172 & 0.16 & 0.13 & 0.70 & -0.03 & -3.8 & 0.11 & -18 & 44 \\
\hline
\end{tabular}

to its higher impact on $\mathrm{PM}_{10}$ values. Over the continent, differences between PM surface concentrations and AOD are partly due to the dilution conditions related to the PBL height due to changes in the vertical mixing and to the moisture content affecting the optical properties of aerosols (Gupta and Christopher, 2009). On the other hand, aerosols in the free troposphere are transported from other regions, significantly contributing to the total AOD (e.g. Amiridis et al., 2005).

Figures 9 and 10 present the mean seasonal $\mathrm{PM}_{10}$ and AOD together with the respective fractions of anthropogenic (nitrate, sulphate, ammonium and $\mathrm{OC}+\mathrm{EC}$ ) and natural aerosols (SSA and desert dust). Despite $\mathrm{SO}_{\mathrm{x}}$ emissions are rather constant throughout the year, a clear seasonal trend is observed in the sulphate contribution to $\mathrm{PM}_{10}$ and $\mathrm{AOD}$ during the warm season due to high temperature and low relative humidity that favour the oxidation of $\mathrm{SO}_{2}$ and the formation of sulphate under the presence of hydroxyl radical (e.g. Querol et al., 2009). In summer, sulphate AOD reaches average values above 0.12 in Eastern Europe, with a maximum of 0.28 over Romania. High surface concentrations of sulphate are calculated in summer over the Aegean Sea $\left(\sim 5 \mu \mathrm{g} \mathrm{m}^{-3}\right)$ due to the shipping traffic emissions and over the Balkans (above $5 \mu \mathrm{g} \mathrm{m}^{-3}$ ) due to emissions from power plants. 

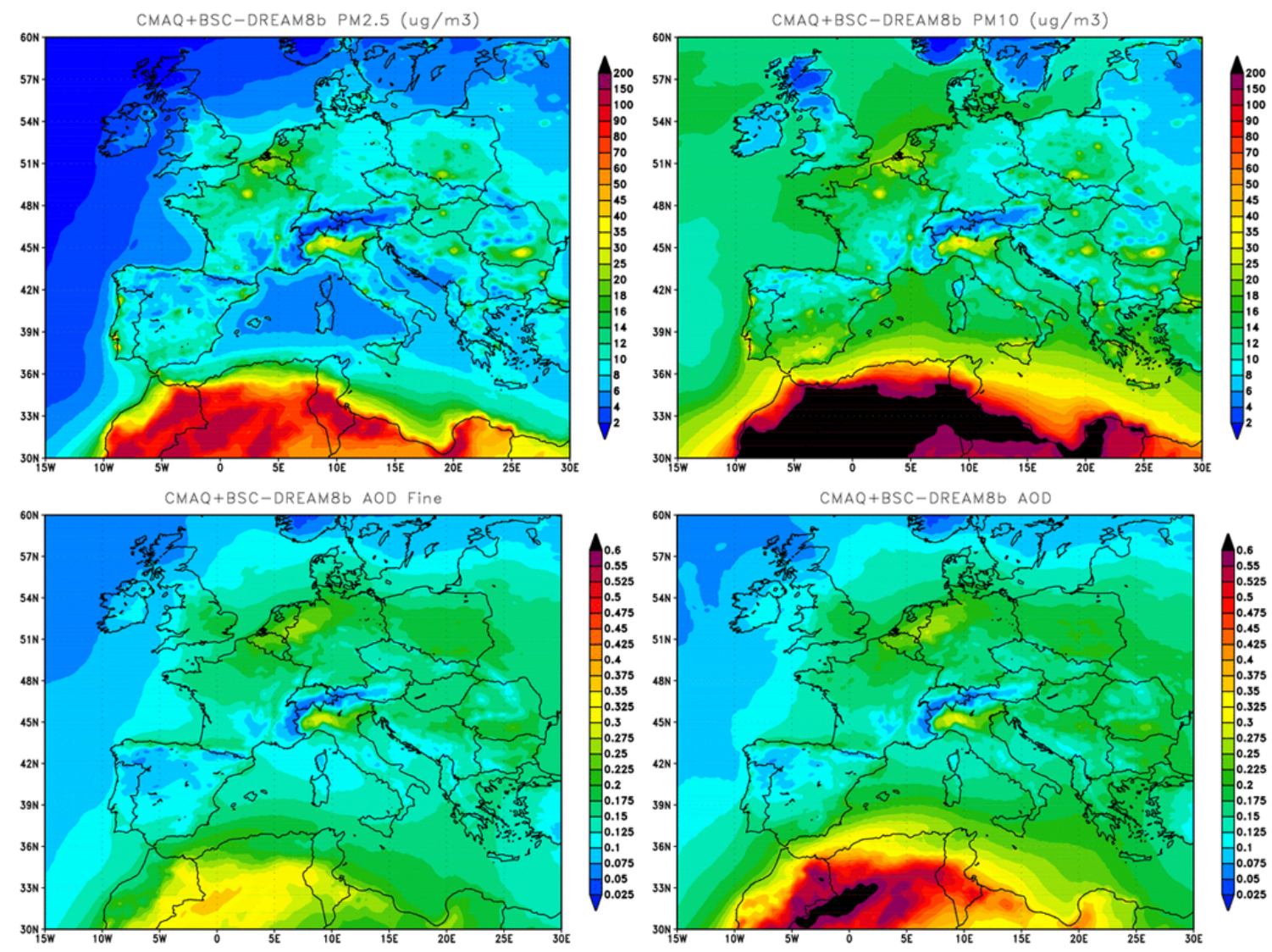

Fig. 8. Annual average of $\mathrm{PM}_{2.5}\left(\right.$ in $\left.\mu \mathrm{g} \mathrm{m}^{-3}\right), \mathrm{PM}_{10}\left(\right.$ in $\left.\mu \mathrm{g} \mathrm{m}^{-3}\right), \mathrm{AOD}_{\text {fine }}$ and AOD obtained with the corrected CMAQ+BSC-DREAM8b simulations. Correction factors of Table 3 are applied to nitrate, sulphate, ammonium and EC + OC.

Nitrate levels also present a strong seasonal variability with the highest values during the cold months (Figs. 9 and 10). In winter the nitrate contribution to $\mathrm{PM}_{10}$ and AOD reaches up to $40 \%$ over the entire European continent. In summer the highest contributions are localised in Central Europe. Ammonium concentration shows only variations throughout the year (Figs. 9 and 10). The highest contributions to $\mathrm{PM}_{10}$ and AOD $(\sim 15 \%$ and $\sim 20 \%$, respectively) are observed in winter and the lowest contributions $(<10 \%)$ in summer. Maximum surface concentrations of nitrate $\left(\sim 4.6 \mu \mathrm{g} \mathrm{m}^{-3}\right)$ and ammonium $\left(\sim 3 \mu \mathrm{g} \mathrm{m}^{-3}\right)$ are simulated over most European countries in winter, with the highest levels over the Po Valley ( $>8 \mu \mathrm{g} \mathrm{m}^{-3}$ and $>5 \mu \mathrm{g} \mathrm{m}^{-3}$ for nitrate and ammonium, respectively). Their maximum contribution to AOD is found in the Po Valley $(\sim 0.10)$ and to a lesser extent in the Benelux area $(\sim 0.08)$.

EC is a primary pollutant so its spatial variability is relatively high. Major sources of EC include diesel engines, particulate heavy-duty trucks, and combustion process (including biomass and fossil fuel), thus high levels are associated with urban areas and maritime routes. Conversely, OC is emitted directly, or in a large proportion formed, from the condensation of low-volatility organic compounds. Thus, the spatial variability of OC is between that of purely primary and secondary pollutants. Major primary sources of OC include diesel and gasoline-burning engines, biomass burning and some industrial processes, so OC will be found in urban and rural background environments. $\mathrm{OC}+\mathrm{EC}$ are concentrated at hot spot locations where they are found in the fine fraction with maximum $\mathrm{PM}_{2.5}$ values of $\sim 6 \mu \mathrm{g} \mathrm{m}^{-3}$ and $\mathrm{AOD}_{\text {fine }}$ values up to 0.01 . Maximum $\mathrm{OC}+\mathrm{EC}$ contributions are observed in summer (Figs. 9 and 10). OC +EC estimations should be taken carefully due to the few measurements available over Europe for the model evaluation results as well as the considerable uncertainties associated to the calculations of EC and OC. Also, SSA contributes weakly to the AOD with an average mean annual value of less than 0.01 . At ground-level, the mean contribution of SSA to $\mathrm{PM}_{10}$ in the Mediterranean Sea reaches up to $40 \%\left(\sim 10 \mu \mathrm{g} \mathrm{m}^{-3}\right)$ and up to $80 \%\left(15 \mu \mathrm{g} \mathrm{m}^{-3}\right)$ in the North Atlantic.

Sulphate and nitrate contribute up to $80 \%$ of the $\mathrm{PM}_{10}$ and AOD in latitudes beyond $41^{\circ} \mathrm{N}$ (Figs. 9 and 10). Maxima SIA and carbonaceous matter are mainly concentrated at hot spot localizations in Europe where they are found in the fine fraction. 

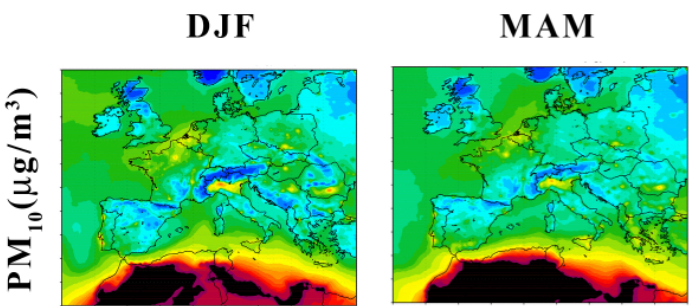

JJA
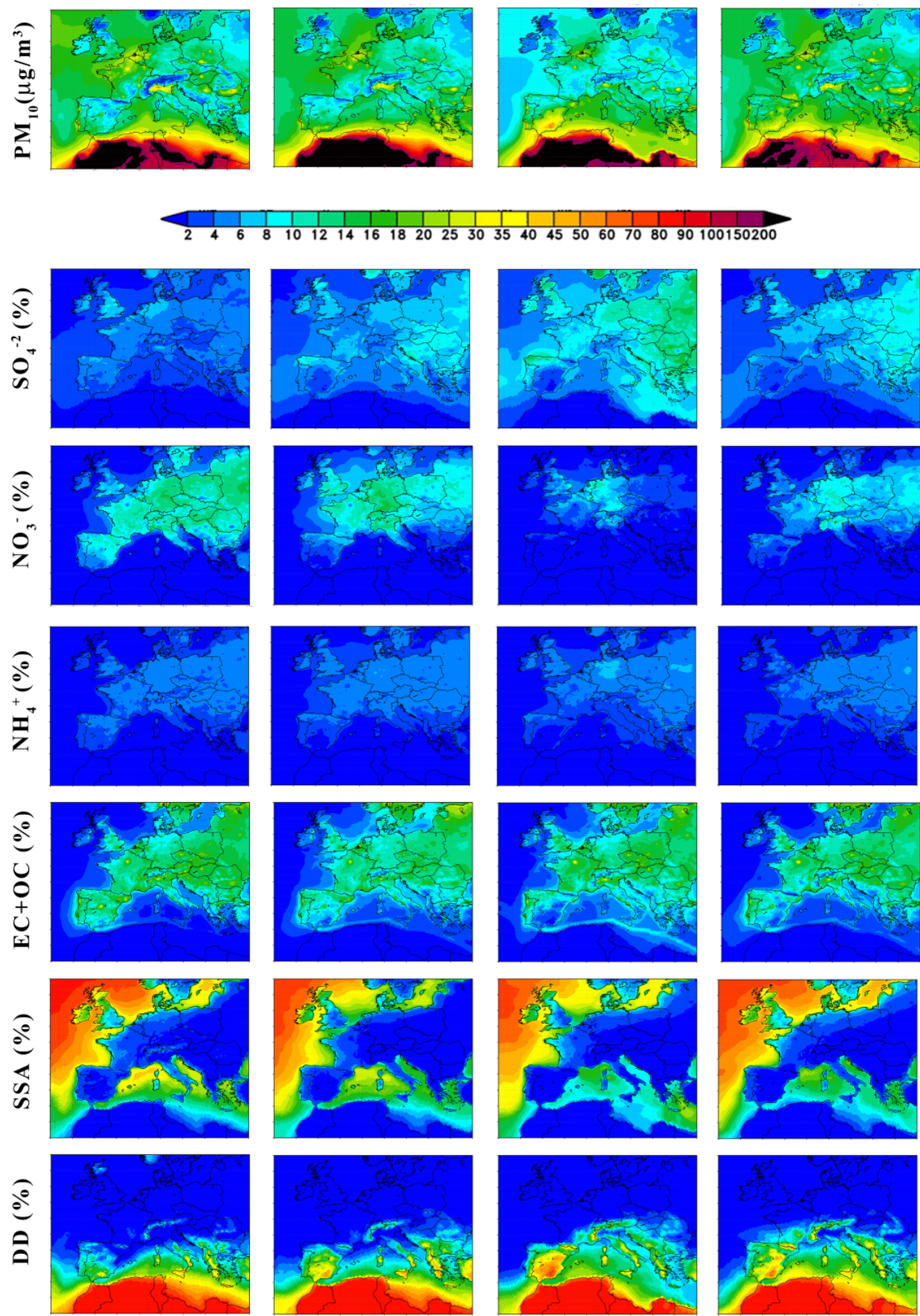
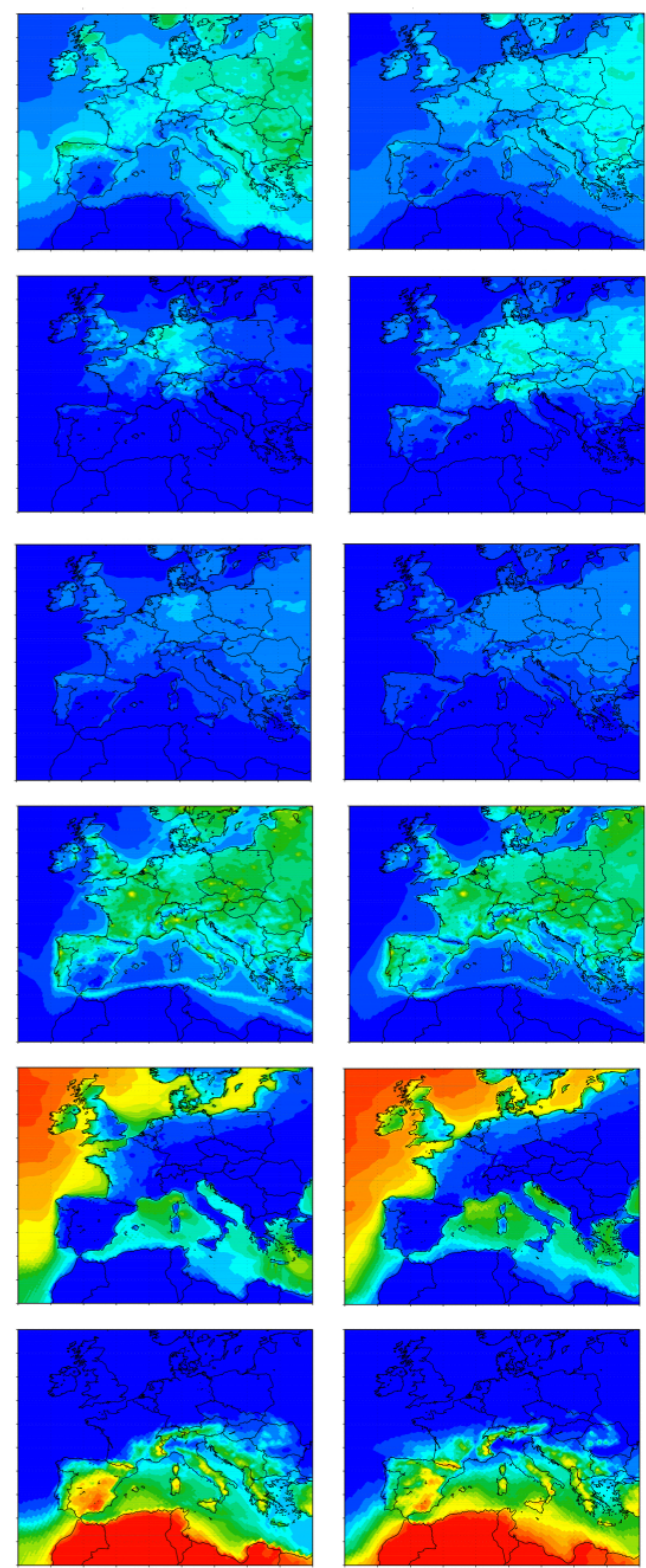

Fig. 9. Seasonal average (from winter to autumn, left to right) of $\mathrm{PM}_{10}$ (in $\mu \mathrm{g} \mathrm{m}^{-3}$ ) and the seasonal contributions (in \%) of sulphate $\left(\mathrm{SO}_{4}^{-2}\right)$, nitrate $\left(\mathrm{NO}_{3}^{-}\right)$, ammonium $\left(\mathrm{NH}_{4}^{-}\right)$, carboneous matter $(\mathrm{EC}+\mathrm{OC})$, sea salt aerosols (SSA) and desert dust (DD) to PM 10 with correction factors applied to sulphate, nitrate, ammonium and $\mathrm{EC}+\mathrm{OC}$. 

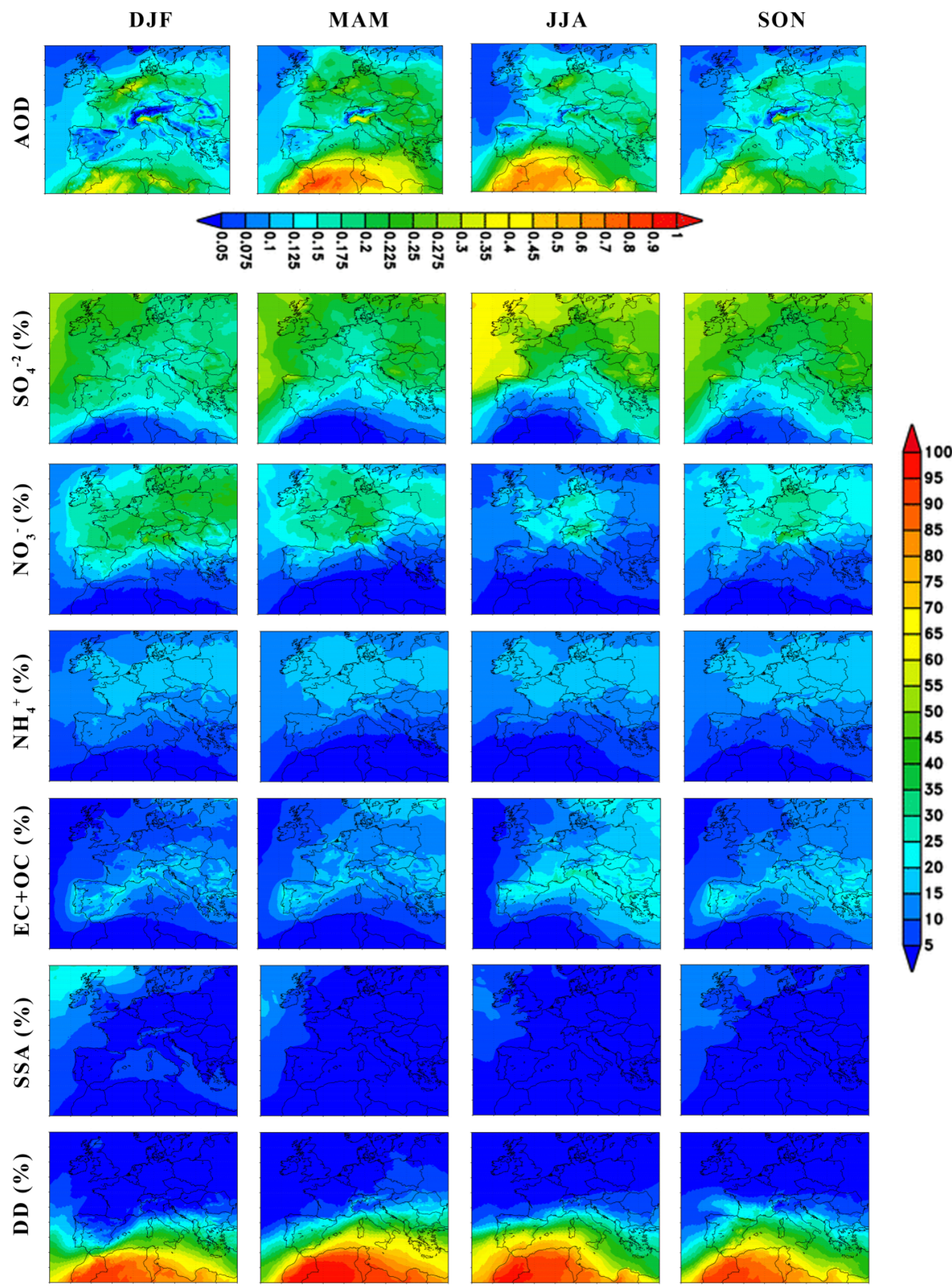

Fig. 10. Seasonal average (from winter to autumn, left to right) of $\mathrm{AOD}$ and the seasonal contributions (in $\%)$ of sulphate ( $\mathrm{SO}_{4}^{-2}$ ), nitrate $\left(\mathrm{NO}_{3}^{-}\right)$, ammonium $\left(\mathrm{NH}_{4}^{-}\right)$, carboneous matter $(\mathrm{EC}+\mathrm{OC})$, sea salt aerosols (SSA) and desert dust (DD) to AOD with correction factors applied to nitrate, sulphate, ammonium and $\mathrm{EC}+\mathrm{OC}$. 
Table 5. Number of exceedances of the $\mathrm{PM}_{10}$ daily European limit value $\left(50 \mu \mathrm{g} \mathrm{m}^{-3}\right)$ from EMEP observations, corrected CMAQ+BSCDREAM8 modelled values and BSC-DREAM8b modelled values. Correction factors of Table 3 are applied to nitrate, sulphate, ammonium and $\mathrm{EC}+\mathrm{OC}$.

\begin{tabular}{lccc}
\hline \multirow{2}{*}{ Station name } & \multicolumn{2}{c}{ Number of exceedances of the PM $_{10}$ daily limit value } \\
\cline { 2 - 4 } & EMEP & CMAQ + BSC-DREAM8b & BSC-DREAM8b \\
\hline Austria_Illmitz_AT0002 & 28 & 1 & 0 \\
Austria_Vorhegg_AT0005 & 1 & 0 & 0 \\
Switzerland_Payerne_CH0002 & 9 & 0 & 0 \\
Switzerland_Tanikon_CH0003 & 7 & 0 & 0 \\
Switzerland_Chaumont_CH0004 & 0 & 0 & 0 \\
Switzerland_Rigi_CH0005 & 0 & 0 & 0 \\
Germany_Westerland_DE0001 & 6 & 0 & 0 \\
Germany_Langenbrugge_DE0002 & 5 & 0 & 0 \\
Germany_Schauinsland_DE0003 & 1 & 0 & 0 \\
Germany_Neuglobsow_DE0007 & 2 & 0 & 0 \\
Germany_Schmucke_DE0008 & 0 & 0 & 0 \\
Germany_Zingst_DE0009 & 5 & 0 & 0 \\
Denmark_Keldsnor_DK0005 & 3 & 0 & 0 \\
Spain_Viznar_ES0007 & 25 & 18 & 0 \\
Spain_Niembro_ES0008 & 0 & 0 & 2 \\
Spain_Campisabalos_ES0009 & 9 & 4 & 0 \\
Spain_Cabo_de_Creus_ES0010 & 0 & 0 & 2 \\
Spain_Barcarrola_ES0011 & 8 & 2 & 4 \\
Spain_Zarra_ES0012 & 9 & 9 & 0 \\
Spain_Penausende_ES0013 & 4 & 1 & 0 \\
Spain_Els_Torms_ES0014 & 15 & 1 & 0 \\
Spain_Risco_Llamo_ES0015 & 10 & 0 & 0 \\
Spain_O_Savinao_ES0016 & 2 & 0 & 0 \\
Spain_Montseny_ES1778 & 7 & & 0 \\
Italy_Montelibretti_IT0001 & 21 & 0 & 0 \\
Italy_Ispra_IT0004 & 71 & 0 & 0 \\
\hline & & 0 & 0 \\
\hline
\end{tabular}
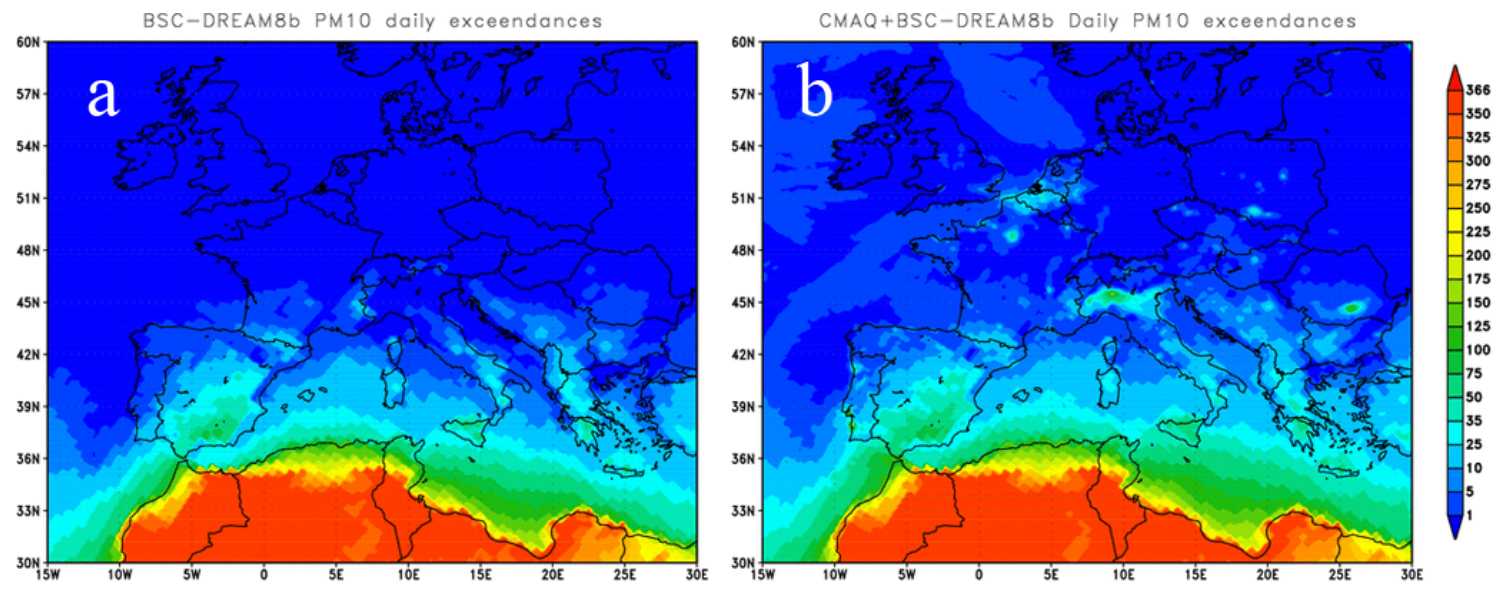

Fig. 11. Number of the days exceeding the EU $\mathrm{PM}_{10}$ daily limit value $\left(>50 \mu \mathrm{g} \mathrm{m}^{-3}\right)$ for (a) BSC-DREAM8b and (b) BSCDREAM8b + CMAQ derived aerosol. Correction factors are applied to sulphate, nitrate, ammonium and EC + OC in CMAQ model outputs. 
In contrast to anthropogenic sources, which are mainly located in the European continent, mineral dust sources affecting Europe's PM levels are mostly found in North African deserts. One distinct feature of the CALIOPE modelling system with respect to other European systems is the inclusion of the influence of African dust on a non-climatological basis by means of the offline coupling with the BSC-DREAM8b model. Desert dust exhibits a strong seasonal variability throughout the year. Maximum desert dust transport to Europe occurs from spring to early autumn according to the model results (Figs. 9 and 10), while minimum desert dust contributions are found in winter over the entire region. In spring, an increase of dust outbreaks and high desert dust contributions $(>40 \%)$ are observed in the Central and Eastern Mediterranean regions. In summer, the maximum desert dust contribution is shifted towards the Western Mediterranean and the Southern Iberian Peninsula. In the Southeastern Iberian Peninsula, desert dust contributes about 60$70 \%$ of the $\mathrm{PM}_{10}$ and AOD levels which reach $40 \mu \mathrm{g} \mathrm{m}^{-3}$ and 0.2 , respectively (Figs. 9 and 10).

The simulated seasonal patterns are in agreement with observational studies using ground-based (e.g. Papayannis et al., 2008; Basart et al., 2009) and satellites observations (e.g. Barnaba and Gobbi, 2004; Antoine and Nobileau, 2006). Long-range transport of Saharan dust across the United Kingdom appears to be much less frequent than for Southern and Central Europe (Ryall et al., 2002) as a consequence of typical atmospheric circulation patterns. Dust particles can penetrate Northern Europe reaching the United Kingdom and the North Sea in winter (contributions to $\mathrm{PM}_{10} \sim 15 \%$ in northern United Kingdom in winter see Fig. 9).

African dust outbreaks have been long recognized to cause exceedances of the European air quality limit values (Rodríguez et al., 2001; Barnaba and Gobbi, 2004; Querol et al., 2004; Papanastasiou et al., 2010). Table 5 shows the number of exceedances of the daily $\mathrm{PM}_{10}$ air quality limit value established by the European Commission $\left(50 \mu \mathrm{g} \mathrm{m}^{-3}\right)$ for each EMEP station in 2004 as well as the number of exceedances obtained with the model. The number of exceedances is underestimated by the CALIOPE modelling system (248 observed days versus 72 simulated days exceeding the daily $\mathrm{PM}_{10}$ limit value). In those stations mostly affected by desert dust outbreaks such as the Spanish EMEP sites, these differences are reduced (with 87 observed versus 37 simulated days exceeding the daily $\mathrm{PM}_{10}$ limit value) indicating the improvement from the inclusion of desert dust in model simulations.

In Fig. 11 we provide a spatial estimate of the number of days in which the daily European air quality limit value $\left(50 \mu \mathrm{g} \mathrm{m}^{-3}\right)$ is not met due to natural dust events. Figure 11a provides an estimate based only on desert dust levels. Large regions from the Iberian Peninsula to Greece (in the North Mediterranean arc, $<45^{\circ} \mathrm{N}$ ) exceed the limit value while the number of daily exceedances increases southwards reaching up to about 75 days per year in the southernmost areas. When we include the other aerosol components (Fig. 11b), a significant number of exceedances appear in well-known European hot spots. In particular, the limit value is exceeded more than 75 days in the Po Valley, Eastern Europe and in the Benelux regions. Additionally in those regions most affected by the presence of desert dust (in the North Mediterranean arc, $<45^{\circ} \mathrm{N}$ ), the number of exceedances notably increases with respect to the desert-dust-alone case achieving up to 100 days in mountainous areas in the South-Eastern Iberian Peninsula. Note that Fig. 11b may only represent a lower end estimate of the total number of exceedances given that the $\mathrm{PM}_{10}$ mass is significantly underestimated in the modelling system (about $6 \mu \mathrm{g} \mathrm{m}^{-3}$ on average).

\section{Summary and conclusions}

A detailed aerosol characterization over Europe for year 2004 using the CALIOPE modelling system has been presented in this work, together with a detailed model evaluation of PM levels, AOD and chemical composition to quantify the model skills and analyze the causes for discrepancy.

The evaluation shows that the modelling system can reproduce reasonably well the daily variability of the main aerosol components in Europe. Aerosol levels are in most cases underestimated. On the one hand, the larger underestimation in $\mathrm{PM}_{10}$ compared to $\mathrm{PM}_{2.5}$ suggests missing sources of coarse PM in the modelling system. On the other hand, the evaluation of the chemical composition highlights important underestimations of the modelled fine fractions particularly for carbonaceous matter $(200 \%)$ and SIA (18-50\%).

We calculated spatially homogenous multiplicative correction factors for carboneous matter and SIA components that minimize the differences between the modelled and observed values. The results of the corrected simulation highlight the fact that besides increasing the total mass budget (underestimations are reduced by $34 \%$ and $23 \%$ for $\mathrm{PM}_{2.5}$ and $\mathrm{PM}_{10}$, respectively), the correction by species and seasons improves the simulation of the variability of the bulk parameters with respect to the observed values (the annual correlation increases from 0.47 to 0.61 for $\mathrm{PM}_{2.5}$, and 0.57 to 0.62 and $\mathrm{PM}_{10}$, respectively). Also the corrected modelled AOD is significantly improved when compared to MODIS.

Aerosols over Europe are dominated by (1) local anthropogenic emissions, (2) the proximity to the African desert and (3) atmospheric dynamics at synoptic scale. The mean annual PM concentration decreases towards the North and North-Western Europe reaching the lowest values in the northernmost regions. The highest aerosol concentrations are found over the industrialized and populated areas of the Po Valley and the Benelux regions. A second maximum is detected over Eastern and Southern Europe. High values over southern Europe are linked to the transport of large particles from the Sahara desert. Maximum values are found in spring 
in the Eastern Mediterranean and in summer over the Iberian Peninsula and the Central-Western Mediterranean. SIA are concentrated in the fine fractions and they are the main contributors to the $\mathrm{PM}_{10}$ and $\mathrm{AOD}$ values in the European continent reaching up to $80 \%$ for latitudes north of $40^{\circ} \mathrm{N}$.

We have shown the importance of the desert dust transported from North Africa in the aerosol budget over Southern European countries. The presence of mineral dust from African deserts causes exceedances of the daily $\mathrm{PM}_{10} \mathrm{Eu}-$ ropean air quality limit value $\left(50 \mu \mathrm{g} \mathrm{m}^{-3}\right)$ in latitudes south of $45^{\circ} \mathrm{N}$ reaching up to more than 75 days per year in the southernmost regions.

Despite the rather satisfactory performance of the modelling system, several aspects are now under further implementation in the framework of the CALIOPE project. Windblown dust should be taken into account especially in dry and arid regions as well as PM resuspension from paved roads in urban areas (Pay et al., 2011). Biomass burning and natural $\mathrm{NO}_{\mathrm{x}}$ are emissions currently not included in the CALIOPE modelling system and could contribute to the $\mathrm{NO}_{2}$ underestimation. Another source of uncertainty comes from the chemical speciation of primary pollutants in the EMEP emission inventory. While in the United States, the Environmental Protection Agency (USEPA) is the common repository of profiles to speciate primary pollutants from different anthropogenic activities, in European modelling exercices there is not a common strategy in this issue. There are different chemical speciation profiles according to different sources of information. Most European emission models (such as Simpson et al., 2012) are based on profiles of NonMethane Volatile Organic Carbon (NMVOC) species from Passant (2002) specifically developed for the United Kingdom. Other European studies such as Bessagnet (2008) used also the profiles from SPECIATE (http://www.epa.gov/ ttnchie1/software/speciate/) which is the USEPA's repository of NMVOC. However, others such as Bieser et al. (2011) used SPECIATE for PM speciation and Passant (2002) for NMVOC. In this sense, it would be recommendable to work in a common European methodology for the chemical speciation of primary emissions.

We expect further progress with the new version of CMAQ (CMAQv5.0) featuring a new aerosol module, AERO5, containing substantial updates in SOA formation and dynamic interactions of fine and coarse aerosol. 


\section{Appendix A}

Table A1. Coordinates, altitude and the aerosol chemical species measured of the 55 selected EMEP stations are included. The code is composed by 2-letter country code plus 4-digit station code. Zone of location is defined in Fig. 1.

\begin{tabular}{|c|c|c|c|c|c|c|c|c|c|c|c|c|c|}
\hline Station Name & Code & Zone & Lat. $\left({ }^{\circ} \mathrm{N}\right)$ & Lon. $\left({ }^{\circ} \mathrm{E}\right)$ & Alt. (m) & Network & $\mathrm{Na}^{+}$ & $\mathrm{Cl}^{-}$ & $\mathrm{SO}_{4}^{-2}$ & $\mathrm{NO}_{3}^{-}$ & $\mathrm{NH}_{4}^{+}$ & OC & $\mathrm{EC}$ \\
\hline Anholt & DK0008 & Nord & 56.717 & 11.517 & 40 & EMEP & $\mathrm{x}$ & & $\mathrm{x}$ & & & & \\
\hline Barcarrota & ES0011 & W.IP & 38.476 & -6.923 & 393 & EMEP & & & $\mathrm{x}$ & $\mathrm{x}$ & & & \\
\hline Birkenes & NO0001 & Nord & 58.383 & 8.250 & 190 & EMEP/CREATE & $\mathrm{x}$ & $\mathrm{x}$ & $\mathrm{x}$ & $\mathrm{x}$ & $\mathrm{x}$ & $\mathrm{x}$ & $\mathrm{x}$ \\
\hline Cabo de Creus & ES0010 & E.IP-W.Med & 42.319 & 3.317 & 23 & EMEP & & & $\mathrm{x}$ & $\mathrm{x}$ & & & \\
\hline Campisábalos & ES0009 & W.IP & 41.281 & -3.143 & 1360 & EMEP & & & $\mathrm{x}$ & $\mathrm{x}$ & & & \\
\hline Chopok & SK0002 & E.Eu & 48.933 & 19.583 & 2008 & EMEP & & & $\mathrm{x}$ & & & & \\
\hline Deuselbach & DE0004 & NW.Eu & 49.767 & 7.050 & 480 & EMEP & & & $\mathrm{x}$ & & & & \\
\hline Diabla Gora & PL0005 & E.Eu & 54.150 & 22.067 & 157 & EMEP & & & $\mathrm{x}$ & & & & \\
\hline Donon & FR0008 & C.Eu & 48.500 & 7.133 & 775 & EMEP & & & $\mathrm{x}$ & & & & \\
\hline Els Torms & ES0014 & E.IP-W.Med & 41.400 & 0.717 & 470 & EMEP & & & $\mathrm{x}$ & $\mathrm{x}$ & & & \\
\hline Eskdalemuir & GB0002 & NW.Eu & 55.313 & -3.204 & 243 & EMEP & & & $\mathrm{x}$ & & & & \\
\hline High Muffles & GB0014 & NW.Eu & 54.334 & -0.808 & 267 & EMEP & & & $\mathrm{x}$ & & & & \\
\hline Illmitz & АT0002 & E.Eu & 47.767 & 16.767 & 117 & EMEP & $\mathrm{x}$ & & $\mathrm{x}$ & $\mathrm{x}$ & $\mathrm{x}$ & & \\
\hline Iraty & FR0012 & S.Fr & 43.033 & -1.083 & 1300 & EMEP & & & $\mathrm{x}$ & & & & \\
\hline Iskrba & SI0008 & N.It & 45.567 & 14.867 & 520 & EMEP & $\mathrm{x}$ & $\mathrm{x}$ & $\mathrm{x}$ & & & & \\
\hline Ispra & IT0004 & N.It & 45.800 & 8.633 & 209 & EMEP & & & $\mathrm{x}$ & $\mathrm{x}$ & $\mathrm{x}$ & & \\
\hline Jarczew & PL0002 & E.Eu & 51.817 & 21.983 & 180 & EMEP & & & $\mathrm{x}$ & $\mathrm{x}$ & $\mathrm{x}$ & & \\
\hline Jungfraujoch & $\mathrm{CH} 0001$ & C.Eu & 46.550 & 7.983 & 3573 & EMEP & & $\mathrm{x}$ & $\mathrm{x}$ & $\mathrm{x}$ & $\mathrm{x}$ & & \\
\hline Kollumerwaard & NL0009 & NW.Eu & 53.334 & 6.277 & 1 & EMEP & & & & $\mathrm{x}$ & $\mathrm{x}$ & & \\
\hline Kosetice & $\mathrm{CZ} 0003$ & E.Eu & 49.583 & 15.083 & 534 & EMEP & & & $\mathrm{x}$ & & & & \\
\hline K-puszta & HU0002 & E.Eu & 46.967 & 19.583 & 125 & EMEP & & & $\mathrm{x}$ & $\mathrm{x}$ & $\mathrm{x}$ & & \\
\hline La Tardière & FR0015 & C.Fr & 46.650 & 0.750 & 746 & EMEP & & & $\mathrm{x}$ & & & & \\
\hline Le Casset & FR0016 & C.Eu & 45.000 & 6.467 & 746 & EMEP & & & $\mathrm{x}$ & & & & \\
\hline Leba & PL0004 & Nord & 54.750 & 17.533 & 2 & EMEP & & & $\mathrm{x}$ & $\mathrm{x}$ & $\mathrm{x}$ & & \\
\hline Liesek & SK0005 & E.Eu & 49.367 & 19.683 & 892 & EMEP & & & $\mathrm{x}$ & $\mathrm{x}$ & & & \\
\hline Lough Navar & GB0006 & N.Atl & 54.443 & -7.870 & 126 & EMEP & & & $\mathrm{x}$ & & & & \\
\hline Melpitz & DE0044 & NW.Eu & 52.53 & 12.93 & 86 & CREATE & $\mathrm{x}$ & $\mathrm{x}$ & $\mathrm{x}$ & $\mathrm{x}$ & $\mathrm{x}$ & $\mathrm{x}$ & $\mathrm{x}$ \\
\hline Montandon & FR0014 & C.Eu & 47.183 & 6.500 & 746 & EMEP & & & $\mathrm{x}$ & & & & \\
\hline Montelibretti & IT0001 & C.Med & 42.100 & 12.633 & 48 & EMEP & & & $\mathrm{x}$ & $\mathrm{x}$ & $\mathrm{x}$ & & \\
\hline Montseny & ES1778 & E.IP-W.Med & 41.778 & 2.3778 & 730 & EMEP & $\mathrm{x}$ & $\mathrm{x}$ & $\mathrm{x}$ & $\mathrm{x}$ & $\mathrm{x}$ & $\mathrm{x}$ & $\mathrm{x}$ \\
\hline Morvan & FR0010 & C.Fr & 47.267 & 4.083 & 620 & EMEP & & & $\mathrm{x}$ & & & & \\
\hline Niembro & ES0008 & W.IP & 43.442 & -4.850 & 134 & EMEP & & & $\mathrm{x}$ & $\mathrm{X}$ & & & \\
\hline O Savñao & ES0016 & W.IP & 42.653 & -7.705 & 506 & EMEP & & & $\mathrm{x}$ & $\mathrm{x}$ & & & \\
\hline Payerne & $\mathrm{CH} 0002$ & C.Eu & 46.817 & 6.950 & 510 & EMEP & & & $\mathrm{x}$ & & & & \\
\hline Penausende & ES0013 & W.IP & 41.283 & -5.867 & 985 & EMEP & & & $\mathrm{x}$ & $\mathrm{x}$ & & & \\
\hline Peyrusse Vieille & FR0013 & S.Fr & 43.375 & 0.104 & 236 & EMEP & & & $\mathrm{x}$ & & & & \\
\hline Preila & LT0015 & Nord & 55.350 & 21.067 & 5 & EMEP & & & $\mathrm{x}$ & & & & \\
\hline Råö & SE0014 & Nord & 57.400 & 11.917 & 5 & EMEP & & & $\mathrm{x}$ & & & & \\
\hline Revin & FR0009 & NW.Eu & 49.900 & 4.633 & 390 & EMEP & & & $\mathrm{x}$ & & & & \\
\hline Rigi & $\mathrm{CH} 0005$ & C.Eu & 47.069 & 8.466 & 1030 & EMEP & & & $\mathrm{x}$ & & & & \\
\hline Risco Llamo & ES0015 & W.IP & 39.517 & -4.350 & 1241 & EMEP & & & $\mathrm{x}$ & $\mathrm{x}$ & & & \\
\hline Rucava & LV0010 & Nord & 56.217 & 21.217 & 5 & EMEP & & & $\mathrm{x}$ & $\mathrm{x}$ & $\mathrm{x}$ & & \\
\hline Skreådalen & NO0008 & Nord & 58.817 & 6.717 & 475 & EMEP & $\mathrm{x}$ & $\mathrm{x}$ & $\mathrm{x}$ & $\mathrm{x}$ & $\mathrm{x}$ & & \\
\hline Sniezka & PL0003 & E.Eu & 50.733 & 15.733 & 1603 & EMEP & & & $\mathrm{x}$ & $\mathrm{x}$ & $\mathrm{x}$ & & \\
\hline Starina & SK0006 & E.Eu & 49.050 & 22.267 & 345 & EMEP & & & $\mathrm{x}$ & $\mathrm{x}$ & & & \\
\hline Svratouch & CZ0001 & E.Eu & 49.733 & 16.033 & 737 & EMEP & & & $\mathrm{x}$ & & & & \\
\hline Tange & DK0003 & Nord & 56.350 & 9.600 & 13 & EMEP & $\mathrm{x}$ & & $\mathrm{x}$ & & & & \\
\hline Topolniky & SK0007 & E.Eu & 47.960 & 17.861 & 113 & EMEP & & & $\mathrm{x}$ & $\mathrm{x}$ & & & \\
\hline Utö & FI0009 & Nord & 59.779 & 21.377 & 7 & EMEP & $\mathrm{x}$ & & $\mathrm{x}$ & & $\mathrm{x}$ & & \\
\hline Valentina Observatory & IE0001 & N.Atl & 51.940 & -10.244 & 11 & EMEP & $\mathrm{x}$ & & $\mathrm{x}$ & & & & \\
\hline Vavihill & SE0011 & Nord & 56.017 & 13.150 & 175 & EMEP & & & $\mathrm{x}$ & & & & \\
\hline Víznar & ES0007 & E.IP-W.Med & 37.233 & -3.533 & 1265 & EMEP & & & $\mathrm{x}$ & $\mathrm{x}$ & & & \\
\hline Yarner Wood & GB0013 & NW.Eu & 50.596 & -3.713 & 119 & EMEP & & & $\mathrm{x}$ & & & & \\
\hline Zarra & ES0012 & E.IP-W.Med & 39.086 & -1.102 & 885 & EMEP & & & $\mathrm{x}$ & $\mathrm{x}$ & & & \\
\hline Zoseni & LV0016 & Nord & 57.133 & 25.917 & 183 & EMEP & & & $\mathrm{x}$ & $\mathrm{X}$ & $\mathrm{x}$ & & \\
\hline
\end{tabular}


Table A2. Description of the 35 AERONET stations. Zone of location is defined in Fig. 1; class of the location: remote (R), urban (U) or sub-rural (S) areas and in littoral locations (C); coordinates, altitude, number of measurements (N), number of hours (Hr.), number of days (Dy.) and months (Mo.), percentage of cloud screened data $(\mathrm{F})$ in the observation period and availability of the quality-assured SDA retrieval products (SDA).

\begin{tabular}{|c|c|c|c|c|c|c|c|c|c|c|c|c|c|c|}
\hline Station name & Code & Zone & Class & $\begin{array}{l}\text { Lon. } \\
\left({ }^{\circ} / \mathrm{E}\right)\end{array}$ & $\begin{array}{l}\text { Lat. } \\
\left({ }^{\circ} / \mathrm{N}\right)\end{array}$ & $\begin{array}{l}\text { Alt. } \\
(\mathrm{m})\end{array}$ & First date & Last date & $\mathrm{N}$ & $\mathrm{Hr}$. & Dy. & Mo. & $\begin{array}{c}\mathrm{F} \\
(\%)\end{array}$ & SDA \\
\hline Avignon & AVI & E.IP-W.Med & $\mathrm{U}$ & 4.88 & 43.93 & 32 & $01 / 01 / 2004$ & $31 / 12 / 2004$ & 7131 & 1998 & 264 & 12 & 34.52 & \\
\hline Barcelona & $\mathrm{BCN}$ & E.IP-W.Med & $\mathrm{U} / \mathrm{C}$ & 2.12 & 41.39 & 125 & $16 / 12 / 2004$ & $31 / 12 / 2004$ & 201 & 59 & 11 & 1 & 39.12 & \\
\hline Belsk & BEL & E.Eu & $\mathrm{R}$ & 20.79 & 51.84 & 190 & $10 / 02 / 2004$ & $11 / 12 / 2004$ & 3173 & 1039 & 150 & 10 & 41.49 & $\mathrm{X}$ \\
\hline Blida & BLI & E.IP-W.Med & $\mathrm{S} / \mathrm{C}$ & 2.88 & 36.51 & 230 & $01 / 01 / 2004$ & $27 / 12 / 2004$ & 4598 & 1368 & 220 & 12 & 33.55 & $\mathrm{x}$ \\
\hline Cabo da Roca & ROC & W.IP & $\mathrm{R} / \mathrm{C}$ & -9.50 & 38.78 & 140 & $04 / 01 / 2004$ & $14 / 10 / 2004$ & 4179 & 1259 & 193 & 10 & 39.17 & \\
\hline Carpentras & CAR & E.IP-W.Med & $\mathrm{R}$ & 5.06 & 44.08 & 100 & $02 / 01 / 2004$ & $15 / 11 / 2004$ & 6905 & 1979 & 242 & 11 & 37.12 & $\mathrm{x}$ \\
\hline Dunkerque & DUN & NW.EU & $\mathrm{U} / \mathrm{C}$ & 2.37 & 51.04 & 0 & $20 / 07 / 2004$ & $06 / 12 / 2004$ & 871 & 331 & 65 & 6 & 56.17 & \\
\hline El Arenosillo & ARE & W.IP & $\mathrm{R} / \mathrm{C}$ & -6.73 & 37.11 & 0 & $01 / 01 / 2004$ & $31 / 12 / 2004$ & 9235 & 2437 & 302 & 12 & 23.70 & \\
\hline ETNA & ETN & C.Med & $\mathrm{U} / \mathrm{C}$ & 15.02 & 37.61 & 736 & $01 / 01 / 2004$ & $15 / 04 / 2004$ & 871 & 226 & 40 & 3 & 39.25 & $\mathrm{x}$ \\
\hline Evora & EVO & W.IP & $\mathrm{U}$ & -7.91 & 38.57 & 293 & $02 / 01 / 2004$ & $31 / 12 / 2004$ & 7860 & 2205 & 266 & 12 & 29.75 & \\
\hline Fontainebleau & FON & NW.EU & $\mathrm{R}$ & 2.68 & 48.41 & 85 & $28 / 03 / 2004$ & $30 / 11 / 2004$ & 1411 & 568 & 106 & 9 & 53.65 & $\mathrm{x}$ \\
\hline Forth Crete & CRE & E.Med & $\mathrm{S} / \mathrm{C}$ & 25,28 & 35,33 & 20 & $01 / 01 / 2004$ & $31 / 12 / 2004$ & 9634 & 2352 & 272 & 12 & 24.90 & $\mathrm{x}$ \\
\hline Hamburg & HAM & NW.EU & $\mathrm{U}$ & 9.97 & 53.57 & 105 & $18 / 01 / 2004$ & $29 / 12 / 2004$ & 2094 & 691 & 115 & 11 & 46.59 & $\mathrm{x}$ \\
\hline Helgoland & HEL & NW.EU & $\mathrm{R} / \mathrm{C}$ & 7.89 & 54.18 & 33 & $28 / 04 / 2004$ & $21 / 10 / 2004$ & 470 & 202 & 40 & 7 & 40.42 & $\mathrm{x}$ \\
\hline IFT-Leipzig & LEI & C.Eu & $\mathrm{U}$ & 12.44 & 51.35 & 125 & $08 / 01 / 2004$ & $21 / 12 / 2004$ & 1567 & 642 & 129 & 12 & 49.15 & $\mathrm{x}$ \\
\hline ISDGM CNR & CNR & N.It & $\mathrm{R} / \mathrm{C}$ & 12.33 & 45.44 & 20 & $01 / 01 / 2004$ & $08 / 11 / 2004$ & 5029 & 1566 & 209 & 11 & 48.26 & $\mathrm{x}$ \\
\hline Ispra & ISP & N.It & S & 8.63 & 45.80 & 235 & $01 / 01 / 2004$ & $31 / 12 / 2004$ & 3942 & 1301 & 200 & 12 & 44.50 & $\mathrm{x}$ \\
\hline Laegeren & LAE & C.Eu & $\mathrm{R}$ & 8.35 & 47.48 & 735 & $30 / 03 / 2004$ & $25 / 12 / 2004$ & 2694 & 848 & 125 & 10 & 41.24 & $\mathrm{x}$ \\
\hline Lampedusa & LAM & C.Med & $\mathrm{R} / \mathrm{C}$ & 12.63 & 35.52 & 45 & $01 / 01 / 2004$ & $30 / 12 / 2004$ & 2561 & 848 & 139 & 8 & 30.63 & \\
\hline Le Fauga & FAU & S.Fr & $\mathrm{R}$ & 1.28 & 43.38 & 193 & $04 / 01 / 2004$ & $22 / 12 / 2004$ & 3736 & 1131 & 176 & 11 & 40.73 & \\
\hline Lecce University & LEC & C.Med & $\mathrm{R}$ & 18.11 & 40.34 & 30 & $01 / 01 / 2004$ & $07 / 10 / 2004$ & 5489 & 1671 & 219 & 10 & 34.28 & $\mathrm{x}$ \\
\hline Lille & LIL & NW.EU & $\mathrm{U}$ & 3.14 & 50.61 & 60 & 03/01/2004 & $29 / 12 / 2004$ & 943 & 346 & 71 & 8 & 51.99 & \\
\hline Mainz & MAI & C.Eu & $\mathrm{S}$ & 8.30 & 50.00 & 150 & $09 / 01 / 2004$ & $30 / 11 / 2004$ & 3191 & 1058 & 172 & 11 & 48.94 & $\mathrm{x}$ \\
\hline Modena & MOD & N.It & $\mathrm{U}$ & 10.95 & 44.63 & 56 & $15 / 03 / 2004$ & $24 / 06 / 2004$ & 1899 & 554 & 70 & 4 & 41.35 & \\
\hline Munich Maisach & MUN & C.Eu & $\mathrm{R}$ & 11.26 & 48.21 & 520 & $22 / 03 / 2004$ & 09/06/2004 & 153 & 74 & 18 & 4 & 48.35 & $\mathrm{x}$ \\
\hline Nicelli Airport & NIC & N.It & $\mathrm{S} / \mathrm{C}$ & 12.38 & 45.43 & 13 & $25 / 08 / 2004$ & 06/09/2004 & 389 & 94 & 10 & 2 & 27.45 & \\
\hline Palaiseau & PLS & NW.EU & S & 2.21 & 48.70 & 156 & $30 / 03 / 2004$ & $29 / 12 / 2004$ & 2725 & 889 & 139 & 10 & 45.08 & \\
\hline Palencia & PAL & W.IP & $\mathrm{U}$ & -4.52 & 41.99 & 750 & $21 / 01 / 2004$ & $30 / 12 / 2004$ & 7389 & 2010 & 265 & 12 & 32.69 & \\
\hline Paris & PAR & NW.EU & $\mathrm{U}$ & 2.33 & 48.87 & 50 & $24 / 11 / 2004$ & $28 / 12 / 2004$ & 106 & 34 & 7 & 2 & 38.59 & \\
\hline Rome Tor Vergata & ROM & C.Med & $\mathrm{R}$ & 12.65 & 41.84 & 130 & $01 / 01 / 2004$ & $31 / 12 / 2004$ & 2256 & 601 & 106 & 8 & 40.05 & \\
\hline SMHI & $\mathrm{SMH}$ & Nord & $\mathrm{U}$ & 16.15 & 58.58 & 0 & $02 / 06 / 2004$ & 08/07/2004 & 493 & 182 & 25 & 2 & 34.73 & $\mathrm{x}$ \\
\hline The Hague & HAG & NW.EU & $\mathrm{S} / \mathrm{C}$ & 4.33 & 52.11 & 18 & $21 / 03 / 2004$ & $21 / 11 / 2004$ & 1376 & 476 & 73 & 7 & 49.67 & \\
\hline Toulon & TUL & E.IP-W.Med & $\mathrm{U} / \mathrm{C}$ & 6.01 & 43.14 & 50 & $15 / 11 / 2004$ & $31 / 12 / 2004$ & 430 & 128 & 24 & 2 & 42.09 & \\
\hline Venise & VEN & N.It & $\mathrm{R} / \mathrm{C}$ & 12.51 & 45.31 & 10 & $01 / 01 / 2004$ & $30 / 12 / 2004$ & 10257 & 1872 & 230 & 12 & 36.34 & \\
\hline Villefranche & VIL & E.IP-W.Med & $\mathrm{S} / \mathrm{C}$ & 7.33 & 43.68 & 130 & $07 / 01 / 2004$ & $10 / 11 / 2004$ & 7120 & 1936 & 235 & 11 & 32.81 & \\
\hline
\end{tabular}


Table A3. Definitions of the statistics used in the study. $o_{i}$ and $c_{i}$ are the observed and the modelled concentrations at time and location $i$, respectively. $n$ : the number of data.

\begin{tabular}{ll}
\hline Statistic Parameter & Formula \\
\hline $\begin{array}{l}\text { Correlation coefficient } \\
(r)\end{array}$ & $r=\frac{\sum_{i=1}^{n}\left(c_{i}-\bar{c}\right) \cdot\left(o_{i}-\bar{o}\right)}{\sqrt{\sum_{i=1}^{n}\left(c_{i}-\bar{c}\right)^{2}} \cdot \sqrt{\sum_{i=1}^{N}\left(o_{i}-\bar{o}\right)^{2}}}$ \\
\hline Mean bias (MB) & $\mathrm{MB}=\frac{1}{n} \sum_{i=1}^{n}\left(c_{i}-o_{i}\right)$ \\
\hline $\begin{array}{l}\text { Root mean square error } \\
\text { RMSE) }\end{array}$ & $\mathrm{RMSE}=\sqrt{\frac{1}{n} \sum_{i=1}^{n}\left(c_{i}-o_{i}\right)^{2}}$ \\
\hline $\begin{array}{l}\text { Mean normalized bias } \\
\text { error (MNBE) }\end{array}$ & $\mathrm{MNBE}=\frac{1}{n} \sum_{i=1}^{n} \frac{\left(c_{i}-o_{i}\right)}{o_{i}} \cdot 100 \%$ \\
\hline $\begin{array}{l}\text { Mean fractionalized } \\
\text { bias (MFB) }\end{array}$ & $\mathrm{MFB}=\frac{1}{n} \sum_{i=1}^{n} \frac{\left(c_{i}-o_{i}\right)}{\left(\frac{c_{i}+o_{i}}{2}\right)} \cdot 100 \%$ \\
\hline $\begin{array}{l}\text { Mean fractionalized } \\
\text { error (MFE) }\end{array}$ & $\mathrm{MFE}=\frac{1}{n} \sum_{i=1}^{n} \frac{\left|c_{i}-o_{i}\right|}{\left(\frac{c_{i}+o_{i}}{2}\right)} \cdot 100 \%$ \\
\hline
\end{tabular}

Acknowledgements. The authors wish to thank EMEP and AERONET for the provision of measurements stations and CIEMAT, CSIC-IJA, CEAM for their collaboration in the CALIOPE project. We also acknowledge the MODIS mission scientists and associated NASA personnel for the production of the data used in this study. Also, special thanks to N. Clave as well M. Piot, L. González and S. Gassó for their work related to the CALIOPE system and S. Szopa and A. Cozic for the provision of LMDz-INCA2 chemical data. This work is partially funded by the CALIOPE project of the Spanish Ministry of the Environment (441/2006/3-12.1, A357/2007/2-12.1, 157/PC08/3-12.0) and the project CICYT CGL2010-19652 of the Spanish Ministry of Education and Science. P. Jiménez-Guerrero acknowledges the Ramón y Cajal Programme of the Spanish Ministry of Science and Technology. All simulations were performed on the MareNostrum supercomputer hosted by the Barcelona Supercomputing CenterCentro Nacional de Supercomputación. Finally, we acknowledge the anonymous reviewers who contributed to improve the quality of the present work.

Edited by: F. Dentener

\section{References}

Amiridis, V., Balis, D. S., Kazadzis, S., Bais, A., Giannakaki, E., Papayannis, A., and Zerefos, C.: Four-year aerosol observations with a Raman lidar at Thessaloniki, Greece, in the framework of European Aerosol Research Lidar Network (EARLINET), Geophys. Res, 110, 1-12, 2005.

Amiridis, V., Kafatos, M., Perez, C., Kazadzis, S., Gerasopoulos, E., Mamouri, R. E., Papayannis, A., Kokkalis, P., Giannakaki, E., Basart, S., Daglis, I., and Zerefos, C.: The potential of the syn- ergistic use of passive and active remote sensing measurements for the validation of a regional dust model, Ann. Geophys., 27, 3155-3164, doi:10.5194/angeo-27-3155-2009, 2009.

Antoine, D. and Nobileau, D.: Recent increase of Saharan dust transport over the Mediterranean Sea, as revealed from ocean color satellite (SeaWiFS) observations, J. Geophys. Res., 111, D12214, doi:10.1029/2005JD006795, 2006.

Appel, K. W., Gilliland, A. B., Sarwar, G., and Gilliam, R. C.: Evaluation of the Community Multiscale Air Quality (CMAQ) model version 4.5: Sensitivities impacting model performance: Part IOzone, Atmos. Environ., 41, 9603-9615, 2007.

Appel, K. W., Bhave, P. V., Gilliland, A. B., Sarwar, G., and Roselle, S. J.: Evaluation of the community multiscale air quality (CMAQ) model version 4.5: Sensitivities impacting model performance; Part II particulate matter, Atmos. Environ., 42, 60576066, doi:10.1016/j.atmosenv.2008.03.036, 2008.

Appel, K. W., Gilliland, A. B., Sarwar, G., and Gilliam, R. C.: Evaluation of the Community Multiscale Air Quality (CMAQ) model version 4.5: Sensitivities impacting model performance: Part I Ozone, Atmos. Environ., 41, 9603-9615, 2007.

Asman, W. A. H.: Modelling the atmospheric transport and deposition of ammonia and ammonium: an overview with special reference to Denmark, Atmos. Environ., 35, 1969-1983, 2001.

Baldasano, J. M., Jiménez-Guerrero, P., Jorba, O., Pérez, C., López, E., Güereca, P., Martín, F., Vivanco, M. G., Palomino, I., Querol, X., Pandolfi, M., Sanz, M. J., and Diéguez, J.J : Caliope: an operational air quality forecasting system for the Iberian Peninsula, Balearic islands and Canary islands e first annual evaluation and ongoing developments, Adv. Sci. Res., 2, 89-98, 2008a.

Baldasano, J. M., Güereca, L. P., López, E., Gassó, S., and JimenezGuerrero, P.: Development of a high-resolution $(1 \mathrm{~km} \times 1 \mathrm{~km}$, $1 \mathrm{~h})$ emission model for Spain: The High-Elective Resolution Modelling Emission System (HERMES), Atmos. Environ., 42, 7215-7233, 2008b.

Baldasano, J. M., Piot, M., Jorba, O., Goncalves, M., Pay, M. T., Basart, S., Jiménez, P., and Gassó, S.: CALIOPE: an Operational Air Quality Forecasting System for Europe and Spain. Mesoscale Modelling For Air Pollution Applications: Achievements And Challenges (COST 728 Final Workshop), Organisers: COST 728, WMO/GURME and MEGAPOLI, Geneva, 25-26 February 2010.

Barnaba, F. and Gobbi, G. P.: Aerosol seasonal variability over the Mediterranean region and relative impact of maritime, continental and Saharan dust particles over the basin from MODIS data in the year 2001, Atmos. Chem. Phys., 4, 2367-2391, doi:10.5194/acp-4-2367-2004, 2004.

Basart, S., Pérez, C., Cuevas, E., Baldasano, J. M., and Gobbi, G. P.: Aerosol characterization in Northern Africa, Northeastern Atlantic, Mediterranean Basin and Middle East from direct-sun AERONET observations, Atmos. Chem. Phys., 9, 8265-8282, doi:10.5194/acp-9-8265-2009, 2009.

Bessagnet, B., Menut, L., Curci, G., Hodzic, A., Guillaume, B., Liousse, C., Moukhtar, S., Pun, B., Seigneur, C., and Schulz, M.: Regional modeling of carbonaceous aerosols over Europe focus on secondary organic aerosols, J. Atmos. Chem., 61, 175202, 2008.

Bieser, J., Aulinger, A., Matthias, V., Quante, M., and Builtjes, P.: SMOKE for Europe - adaptation, modification and evaluation of a comprehensive emission model for Europe, Geosci. Model 
Dev., 4, 47-68, doi:10.5194/gmd-4-47-2011, 2011.

Binkowski, F. S.: Aerosols in MODELS-3 CMAQ, in: Science Algorithms of the EPA Models-3 Community Multiscale Air Quality (CMAQ) Modeling System, edited by: Byun, D. W. and Ching, J. K. S., 10-0-10-23, EPA, 1999.

Binkowski, F. S. and Roselle, S. J.: Models-3 Community Multiscale Air Quality (CMAQ) model aerosol component. 1. Model description, J. Geophys. Res., 108, 4183, doi:10.1029/2001JD001409, 2003.

Bond, T. C., Streets, D. G. Yarber, K. F., Nelson, S. M., Woo, J. H., and Klimont, Z.: A technology-based global inventory of black and organic carbon emissions from combustion, J. Geophys. Res. Atmos., 109, D14203, doi:10.1029/2003JD003697, 2004.

Boylan, J. W. and Russell, A. G.: PM and light extinction model performance metrics, goals, and criteria for three-dimensional air quality models, Atmos. Environ., 40, 4946-4959, 2006.

Byun, D. W. and Ching, J. K. S.: Science Algorithms of the EPA Models-3 Community Multiscale Air Quality (CMAQ) Modeling System, Atmospheric modeling division, National Exposure Research Laboratory, US Environmental Protection Agency, Research Triangle Park, NC, 27711, 1999.

Byun, D. W. and Schere, K. L.: Review of the Governing Equations, Computational Algorithms, and Other Components of the Models-3 Community Multiscale Air Quality (CMAQ) Modeling System, Appl. Mech. Rev., 59, 27 pp., 2006.

Chang, J. C. and Hanna, S. R.: Air quality model performance evaluation, Meteorol. Atmos. Phys., 87, 167-196, 2004.

Cooke, W. F. and Wilson, J. J. N.: A global black carbon aerosol model, J. Geophys. Res. Atmos., 101, 19395-19409, 1996.

Cox, W. M. and Tikvart, J. A.: A statistical procedure for determining the best performing air quality simulation model, Atmos. Environ. A-Gen., 24, 2387-2395, 1990

Dennis, R., Fox, T., Fuentes, M., Gilliland, A., Hanna, S., Hogrefe, C., Irwin, J., Rao, S. T., Scheffe, R., and Schere, K.: A framework for evaluating regional-scale numerical photochemical modeling systems, Environ. Fluid Mech., 10, 1-19, 2010.

Djalalova, I., Wilczak, J., McKeen, S., Grell, G., Peckham, S., Pagowski, M., Delle Monache, L., McQueen, J., Tang, Y., Lee, P., McHenry, J., Gong, W., Bouchet, V., and Mathru, R.: Ensemble and bias-correction techniques for air quality model forecasts of surface $\mathrm{O}_{3}$ and $\mathrm{PM}_{2.5}$ during the TEXAQS-II experiment of 2006, Atmos. Environ., 44, 455-467, 2010.

Dubovik, O. and King, M. D.: A flexible inversion algorithm for retrieval of aerosol optical properties from sun and sky radiance measurements, J. Geophys. Res., 105, 20676, doi:10.1029/2000JD900282, 2000.

Dubovik, O., Holben, B. N., Eck, T. F., Smirnov, A., Kaufman, Y. J., King, M. D., Tanré, D., and Slutsker, I.: Variability of Absorption and Optical Properties of Key Aerosol Types Observed in Worldwide Locations, Atmos. Sci., 59, 590-608, 2002.

Eder, B. and Yu, S.: A performance evaluation of the 2004 release of models-3 CMAQ, Atmos. Environ., 40, 4811-4824, doi:10.1016/j.atmosenv.2005.08.045, 2006.

Edney, E. O., Kleindienst, T. E., Lewandowski, M., and Offenberg, J. H.: Updated SOA chemical mechanism for the community multi-scale air quality model, EPA 600/X-07/025, US Environmental Protection Agency, Research Triangle park, North Carolina, 2007.

EMEP: National Emissions Reported to the Convention on Long- range Transboundary Air Pollution (LRTAP Convention). Air Emission Annual Data Reporting (EMEP/MSC-W), Technical Report, European Environmental Agency, The Norwegian Meteorological Institute, Oslo, Norway, 2007.

European Commission: Directive 2008/50/EC of the European Parliament and of the Council of 21 May 2008 on Ambient Air Quality and Cleaner Air for Europe, Technical Report 2008/50/EC, L152, Off. J. Eur. Comm., 2008.

European Commission: Forest fires in Europe 2004. Report 5. Official Publication of the European Commission. S.P.I.05.147 EN (Source: http://www.fire.uni-freiburg.de/programmes/ eu-comission/EU-Forest-Fires-in-Europe-2004.pdf), 2005.

Folberth, G. A., Hauglustaine, D. A., Lathière, J., and Brocheton, F.: Interactive chemistry in the Laboratoire de Météorologie Dynamique general circulation model: model description and impact analysis of biogenic hydrocarbons on tropospheric chemistry, Atmos. Chem. Phys., 6, 2273-2319, doi:10.5194/acp-62273-2006, 2006.

Gery, M. W., Whitten, G. Z., Killus, J. P., and Dodge, M. C.: A photochemical kinetics mechanism for urban and regional scale computer modeling, J. Geophys. Res., 94, 12925-12956, 1989.

Gilliland, A. B., Dennis, R. L., Roselle, S. J., and Pierce, T. E.: Seasonal NH3 emission estimates for the eastern United States based on ammonium wet concentrations and an inverse modeling method, J. Geophys. Res., 108, 4477, doi:10.1029/2002JD003063, 2003.

Gobbi, G. P., Kaufman, Y. J., Koren, I., and Eck, T. F.: Classification of aerosol properties derived from AERONET direct sun data, Atmos. Chem. Phys., 7, 453-458, doi:10.5194/acp-7-453-2007, 2007.

Gong, S. L.: A parameterization of sea-salt aerosol source function for sub- and super-micron particles, J. Geophys. Res., 17, 1097, doi:10.1029/2003GB002079, 2003.

Gupta, P. and Christopher, S. A.: Particulate matter air quality assessment using integrated surface, satellite, and meteorological products: Multiple regression approach, J. Geophys. Res., 114, D14205, doi:10.1029/2008JD011496, 2009.

Hauglustaine, D. A., Hourdin, F., Jourdain, L., Filiberti, M. A.,Walters, S., Lamarque, J. F., and Holland, E. A.: Interactive chemistry in the Laboratoire de Meteorologie Dynamique general circulation model: description and background tropospheric chemistry evaluation, J. Geophys. Res., 109, D04314, doi:10.1029/2003JD003957, 2004.

Haustein, K., Pérez, C., Baldasano, J. M., Müller, D., Tesche, M., Schladitz, A., Esselborn, M., Weinzierl, B., Kandler, K., and Hoyningen-Huene, W. v.: Regional dust model performance during SAMUM 2006, Geophys. Res. Lett., 36, L03812, doi:10.1029/2008GL036463, 2009.

Hogrefe, C., Hao, W., Civerolo, K., Ku, J. Y., and Sistla, G: Exploring approaches to integrate observations and CMAQ simulations for improved air quality forecasts, Presented at the 5th nnual CMAQ User's Conference, Chapel Hill, NC, available at: http://www.cmascenter.org/conference/2006/abstracts/ hogrefe_session3.pdf, 2006.

Holben, B. N., Eck, T. F., Slutsker, I., Tanré, D., Buis, J. P., Setzer, A., Vermote, E., Reagan, J., Kaufman, Y., Nakajima, T., Lavenu, F., Jankowiak, I., and Smirnov, A.: AERONET: A Federated Instrument Network and Data Archive for Aerosol Characterization, Remote Sens. Environ., 66, 1-16, 1998. 
IPCC, Intergovernmental Panel on Climate Change: Climate change 2007: Synthesis Report, http://www.ipcc.ch/ publications_and_data/ar4/syr/en/main.html, 2007.

Jiménez, P., Baldasano, J. M., and Dabdub, D.: Comparison of photochemical mechanisms for air quality modelling, Atmos. Environ., 37, 4179-4194, doi:10.1016/S1352-2310(03)00567-3, 2003.

Jiménez-Guerrero, P., Jorba, O., Baldasano, J. M., and Gassó, S.: The use of a modelling system as a tool for air quality management: Annual high-resolution simulations and evaluation, Sc. Total Environ., 390, 323-340, 2008.

Kang, D., Mathur, R., and Trivikrama Rao, S.: Assessment of bias-adjusted $\mathrm{PM}_{2.5}$ air quality forecasts over the continental United States during 2007, Geosci. Model Dev., 3, 309-320, doi:10.5194/gmd-3-309-2010, 2010.

Kasibhatla, P., Chameides, W. L., and Jonn, J. S.: A three dimensional global model investigation of seasonal variations in the atmospheric burden of anthropogenic sulphate aerosols, J. Geophys. Res., 102, 3737-3759, 1997.

Keenan, T., Niinemets, Ü., Sabate, S., Gracia, C., and Peñuelas, J.: Process based inventory of isoprenoid emissions from European forests: model comparisons, current knowledge and uncertainties, Atmos. Chem. Phys., 9, 4053-4076, doi:10.5194/acp-94053-2009, 2009.

Kelly, J. T., Bhave, P. V., Nolte, C. G., Shankar, U., and Foley, K. M.: Simulating emission and chemical evolution of coarse seasalt particles in the Community Multiscale Air Quality (CMAQ) model, Geosci. Model Dev., 3, 257-273, doi:10.5194/gmd-3257-2010, 2010.

Larssen, S., Sluyter, R., and Helmis, C.: Criteria for EUROAIRNET, the EEA Air Quality Monitoring and Information Network, Technical Report No. 12, European Environment Agency, http://reports.eea.eu.int/TEC12/en, 1999.

Levy, R. C., Remer, L. A., Tanré, D., Kaufman, Y. J., Ichoku, C., Holben, B. N., Livingston, J. M., Russell, P. B., and Maring, H.: Evaluation of the Moderate-Resolution Imaging Spectroradiometer (MODIS) retrievals of dust aerosol over the ocean during PRIDE, J. Geophys. Res., 108, 8594, doi:10.1029/2002JD002460, 2003.

Mallet, M., Roger, J. C., Despiau, S., Dubovik, O., and Putaud, J. P.: Microphysical and optical properties of aerosol particles in urban zone during ESCOMPTE, Atmos. Res., 69, 73-97, 2003.

Malm, W. C., Sisler, J. F., Huffman, D., Eldred, R. A., and Cahill, T. A.: Spatial and seasonal trends in particle concentration and optical extinction in the United States, J. Geophys. Res., 99, 13471370, 1994.

Manders, A. M. M., Schaap, M., and Hoogerbrugge, R.: Testing the capability of the chemistry transport model LOTOS-EUROS to forecast $\mathrm{PM}_{10}$ levels in the Netherlands, Atmos. Environ., 43, 4050-4059, 2009.

Matthias, V.: The aerosol distribution in Europe derived with the Community Multiscale Air Quality (CMAQ) model: comparison to near surface in situ and sunphotometer measurements, Atmos. Chem. Phys., 8, 5077-5097, doi:10.5194/acp-8-5077-2008, 2008.

McKeen, S., Wilczak, J., Grell, G., Djalalova, I., Peckham, S., Hsie, E. Y., Gong, W., Bouchet, V., Menard, S., and Moffet, R.: Assessment of an ensemble of seven real-time ozone forecasts over eastern North America during the summer of 2004, J. Geophys.
Res., 110, D21307, doi:10.1029/2006JD007598, 2005.

Medina, S., Le Tertre, A., and Saklad, M.: The APHEIS Project: air pollution and health - a European information system, Air Quality, Atmosphere and Health, 2, 185-198, 2009.

Mélin, F. and Zibordi, G.: Aerosol variability in the Po Valley analyzed from automated optical measurements, Geophys. Res. Lett., 32, L03810, doi:10.1029/2004GL021787, 2005.

Meng, Z., Dabdub, D., and Seinfeld, J. H.: Chemical coupling between atmospheric ozone and particulate matter, Science, 277 , 116-119, 1997.

Menut, L. and Bessagnet, B.: Atmospheric composition forecasting in Europe, Ann. Geophys., 28, 61-74, doi:10.5194/angeo-28-612010, 2010.

Michalakes, J., Dudhia, J., Gill, D., Henderson, T., Klemp, J., Skamarock, W., and Wang, W.: The weather research and forecast model: software architecture and performance, To Appear in Proceeding of the Eleventh ECMWF Workshop on the Use of High Performance Computing in Meteorology, edited by: Mozdzynski, E. G., 25-29 October 2004, Reading, UK, 156168, 2004.

Middleton, N. J. and Goudie, A. S.: Saharan dust: sources and trajectories, Trans. Inst. Br. Geogr., 26, 165, doi:10.1111/14755661.00013, 2001.

Monks, P. S., Granier, C., Fuzzi, S., Stohl, A., ,Williams, M. L., Akimoto, H., Amann, M., Baklanov, A., Baltensperger, U., Bey, I., Blake, N., Blake, R. S., Carslaw, K., Cooper, O. R., Dentener, F., Fowler, D., Fragkou, E., Frost, G.J., Generoso, S., Ginoux, P., Grewe, V., Guenther, A., Hansson, H. C., Henne, S., Hjorth, J., Hofzumahaus, A., Huntrieser, H. , Isaksen, I. S. A., Jenkin, M. E., Kaiser, J. M., Kanakidou, Klimont, Z., Kulmala, M., Laj, P., Lawrence, M. G., Lee, J. D., Liousse, C. M., Maione, McFiggans, G., Metzger, A., Mieville, A., Moussiopoulos, N., Orlando, J.J., O’Dowd, C.D., Palmer, P. I., Parrish, D. D., Petzold, A., Platt, U., Pöschl, U., Prévôt, A. S. H., Reeves, C. E. S., Reimann, Rudich, Y., Sellegri, K., Steinbrecher, R., Simpson, D., ten Brink, H., Theloke, J., van der Werf, G. R., Vautard, R., Vestreng, V., Vlachokostas, Ch., and von Glasow, R.: Atmospheric composition change - global and regional air quality, Atmos. Environ., 43, 5268-5350, 2009.

Nenes, A., Pilinis, C., and Pandis, S. N.: ISORROPIA: A New Thermodynamic Equilibrium Model for Multiphase Multicomponent Inorganic Aerosols, Aquat. Geochem., 4, 123-152, doi:10.1023/A:1009604003981, 1998.

Nickovic, S., Kallos, G., Papadopoulos, A., and Kakaliagou, O.: A model for prediction of desert dust cycle in the atmosphere, J. Geophys. Res., 106, 18113-18129, doi:10.1029/2000JD900794, 2001.

O’Neill, N. T., Dubovik, O., and Eck, T. F.: A modified Angstrom coefficient for the characterization of sub-micron aerosols, Appl. Optics, 40, 2368-2375, 2001.

O’Neill, N. T., Eck, T. F., Smirnov, A., Holben, B. N., and Thulasiraman, S.: Spectral discrimination of coarse and fine mode optical depth, J. Geophys. Res., 108, 4559, doi:10.1029/2002JD002975, 2003.

Papanastasiou, D. K., Poupkou, A., Katragkou, E., Amiridis, V., Melas, D., Mihalopoulos, N., Basart, S., Pérez, C., and Baldasano, J. M.: An Assessment of the Efficiency of Dust Regional Modelling to Predict Saharan Dust Transport Episodes, Advances in Meteorology, 2010, 154368, 
doi:10.1155/2010/154368, 2010.

Papayannis, A., Amiridis, V., Mona, L., Tsaknakis, G., Balis, D., Bösenberg, J., Chaikovski, A., De Tomasi, F., Grigorov, I., and Mattis, I.: Systematic lidar observations of Saharan dust over Europe in the frame of EARLINET (2000-2002), Geophys. Res., 113, D10204, doi:10.1029/2007JD009028, 2008.

Passant, N.: Speciation of UK emissions of non-methane volatile organic compounds. AEA Technology, Culham Abingdon Oxon. GB, AEAT/ENV/0545, 2002.

Pay, M. T., Piot, M., Jorba, O., Gassó, S., Gonçalves, M., Basart, S., Dabdub, D., Jiménez-Guerrero, P., and Baldasano, J. M.: A Full Year Evaluation of the CALIOPE-EU Air Quality Modeling System over Europe for 2004, Atmos. Environ., 44, 3322-3342, doi:10.1016/j.atmosenv.2010.05.040, 2010.

Pay, M. T., Jiménez-Guerrero, P., and Baldasano, J. M.: Implementation of resuspension from paved roads for the improvement of CALIOPE air quality system in Spain, Atmos. Environ., 45, 802 807, doi:10.1016/j.atmosenv.2010.10.032, 2011

Péré, J. C., Mallet, M., Pont, V., and Bessagnet, B.: Evaluation of an aerosol optical scheme in the chemistrytransport model CHIMERE, Atmos. Environ., 44, 3688-3699, doi:10.1016/j.atmosenv.2010.06.034, 2010.

Pérez, C., Nickovic, S., Baldasano, J. M., Sicard, M., Rocadenbosch, F., and Cachorro, V. E.: A long Saharan dust event over the western Mediterranean: Lidar, Sun photometer observations, and regional dust modeling, J. Geophys. Res., 111, D15214, doi:10.1029/2005JD006579, 2006a.

Pérez, C., Nickovic, S., Pejanovic, G., Baldasano, J. M., and Ozsoy, E.: Interactive dust-radiation modeling: A step to improve weather forecasts, J. Geophys. Res., 11, D16206, doi:10.1029/2005JD006717, 2006b.

Piot, M., Jorba, O., Jimenez, P., and Baldasano, J. M.: The Role of Lateral Boundary Conditions and Boundary Layer in Air Quality Modelling System, Eos Trans. AGU, 8, H212+, Abstract A41H0212, 2008

Pope, C. A. I., Ezzati, M., and Dockery, D. W.: Fine-Particulate Air Pollution and Life Expectancy in the United States, The New England Journal Med., 360, 376-386, 2009.

Putaud, J.-P., Van Dingenen, R., Mangoni, M., Virkkula, A., Raes, F., Maring, H., Prospero, J. M., Swietlicki, E., Berg, O. H., Hillamo, R., and Mäkelä, T.: Chemical mass closure and assessment of the origin of the submicron aerosol in the marine boundary layer and the free troposphere at Tenerife during ACE2, Tellus, 52B, 147-168, 2000.

Putaud, J.-P., Raes, F., Van Dingenen, R., Bruggemann, E., Facchini, M. C., Decesari, S., Fuzzi, S., Gehrig, R., Huglin, C., Laj, P., Lorbeer, G., Maenhaut, W., Mihalopoulos, N., Müller, K., Querol, X., Rodríguez, S., Schneider, J., Spindler, G., ten Brink, H., Torseth, K., and Wiedensohler, A.: European aerosol phenomenology 2: chemical characteristics of particulate matter at kerbside, urban, rural and background sites in Europe, Atmos. Environ., 38, 2579-2595, 2004.

Querol, X., Alastuey, A., Viana, M., Rodríguez, S., Artiano, B., Salvador, P., Santos, S. G. d., Patier, R. F., Ruiz, C. R., Rosae, J. d. 1., Campa, A. S. d. 1., Menendez, M., and Gilf, J. I.: Speciation and origin of $\mathrm{PM}_{10}$ and $\mathrm{PM}_{2.5}$ in Spain, Aerosol Sci., 35, 11511172, doi:10.1016/j.jaerosci.2004.04.002, 2004.

Querol, X., Alastuey, A., Pey, J., Cusack, M., Pérez, N., Mihalopoulos, N., Theodosi, C., Gerasopoulos, E., Kubilay, N., and Koçak, M.: Variability in regional background aerosols within the Mediterranean, Atmos. Chem. Phys., 9, 4575-4591, doi:10.5194/acp-9-4575-2009, 2009.

Remer, L. A., Kaufman, Y. J., Tanré, D., Mattoo, S., Chu, D. A., Martins, J. V., Li, R. R., Ichoku, C., Levy, R. C., Kleidman, R. G., Eck, T. F., Vermote, E., and Holben, B. N.: The MODIS Aerosol Algorithm, Products, and Validation, J. Atmos. Sci., 62, 947-973, 2005.

Rodríguez, S., Querol, X., Alastuey, A., Kallos, G., and Kakaliagou, O.: Saharan dust contributions to $\mathrm{PM}_{10}$ and TSP levels in Southern and Eastern Spain, Atmos. Environ., 35, 2433-2447, 2001.

Rodríguez, S., Querol, X., Alastuey, A., and Plana, F.: Sources and processes affecting levels and composition of atmospheric aerosol in the Western Mediterranean, J. Geophys. Res., 107, 4777, doi:10.1029/2001JD001488, 2002.

Rodríguez, S., Alastuey, A., Alonso-Pérez, S., Querol, X., Cuevas, E., Abreu-Afonso, J., Viana, M., Pérez, N., Pandolfi, M., and de la Rosa, J.: Transport of desert dust mixed with North African industrial pollutants in the subtropical Saharan Air Layer, Atmos. Chem. Phys., 11, 6663-6685, doi:10.5194/acp-11-66632011, 2011.

Roy, B., Mathur, R., Gilliland, A. B., and Howard, S. C.: A comparison of CMAQ-based aerosol properties with IMPROVE, MODIS, and AERONET data, Geophys. Res, 112, D14301, doi:10.1029/2006JD008085, 2007.

Ryall, D. B., Derwent, R. G., Manning, A. J., Redington, A. L., Corden, J., Millington, W., Simmonds, P. G., O'Doherty, S., Carslaw, N., and Fuller, G. W.: The origin of high particulate concentrations over the United Kingdom, March 2000, Atmos. Environ., 36, 1363-1378, 2002.

Schaap, M., van Loon, M., ten Brink, H. M., Dentener, F. J., and Builtjes, P. J. H.: Secondary inorganic aerosol simulations for Europe with special attention to nitrate, Atmos. Chem. Phys., 4, 857-874, doi:10.5194/acp-4-857-2004, 2004.

Schell, B., Ackermann, I. J., Hass, H., Binkowski, F. S., and Ebel, A.: Modeling the formation of secondary organic aerosol within a comprehensive air quality model system, J. Geophys. Res., 106 28275-28293, doi:2001JD000384, 2001.

Seinfeld, J. H. and Pandis, S. N.: Atmospheric Chemistry and Physics: From Air Pollution to Climate Change, John Wiley, New York, 1326 pp., 1998.

Sicardi, V., Ortiz, J., Rincón, A., Jorba, O., Pay, M. T., Gassó, S., and Baldasano, J. M.: Ground-level ozone concentration over Spain: an application of Kalman Filter post-processing to reduce model uncertainties, Geosci. Model Dev. Discuss., 4, 343-384, doi:10.5194/gmdd-4-343-2011, 2011.

Skamarock, W. C. and Klemp, J. B.: A time-split nonhydrostatic atmospheric model for weather research and forecasting applications. J. Comput. Phys., 227, 3465-3485, doi:10.1016/j.jcp.2007.01.037, 2008.

Smirnov, A., Holben, B. N., Eck, T. F., Dubovik, O., and Slutsker, I.: Cloud screening and quality control algorithms for the AERONET database, Remote Sens. Environ., 73, 337-349, 2000.

Simpson, D., Benedictow, A., Berge, H., Bergström, R., Emberson, L. D., Fagerli, H., Hayman, G. D., Gauss, M., Jonson, J. E., Jenkin, M. E., Nyíri, A., Richter, C., Semeena, V. S., Tsyro, S., Tuovinen, J.-P., Valdebenito, Á., and Wind, P.: The EMEP MSCW chemical transport model - Part 1: Model description, Atmos. 
Chem. Phys. Discuss., 12, 3781-3874, doi:10.5194/acpd-123781-2012, 2012.

Szopa, S., Foret, G., Menut, L., and Cozic, A.: Impact of large scale circulation on European summer surface ozone and consequences for modelling forecast, Atmos. Environ., 43, 11891195, 2009.

Tang, I. N., Wong, W. T., and Munkelwitz, H. R.: The relative importance of atmospheric sulfates and nitrates in visibility reduction, Atmos. Environ., 15, 2463-2471, 1981.

Tegen, I. and Lacis, A. A.: Modeling of particle size distribution and its influence on the radiative properties of mineral dust aerosol, J. Geophys. Res., 101, 19237-19244, 1996.

Todd, M. C.: Quantifying uncertainty in estimates of mineral dust flux: An intercomparison of model performance over the Bodélé Depression, Northern Chad, Geophys. Res, 113, D24107, doi:10.1029/2008JD010476, 2008.

Tombette, M., Chazette, P., Sportisse, B., and Roustan, Y.: Simulation of aerosol optical properties over Europe with a 3-D sizeresolved aerosol model: comparisons with AERONET data, Atmos. Chem. Phys., 8, 7115-7132, doi:10.5194/acp-8-7115-2008, 2008.

Torseth, K. and Hov, O.: The EMEP Monitoring Strategy 20042009, Technical report 9/2003, EMEP/CCC, 2003.

Tsyro, S. G.: To what extent can aerosol water explain the discrepancy between model calculated and gravimetric $\mathrm{PM}_{10}$ and $\mathrm{PM}_{2.5}$ ?, Atmos. Chem. Phys., 5, 515-532, doi:10.5194/acp-5515-2005, 2005.
Tsyro, S., Simpson, D., Tarrasón, L., Klimont, Z., Kupiainen, K., Pio, C., and Yttri, K. E.: Modeling of elemental carbon over Europe, J. Geophys. Res. 112, D23S19, doi:10.1029/2006JD008164, 2007.

US EPA: Interim Procedures for Evaluating Air Quality Models (Revised), Technical Report, EPA-450/4-91-013, US Environmental Protection Agency, Office of Air Quality Planning and Standards, Research Triangle Park, NC, 1984.

US EPA: Guideline for Regulatory Application of the Urban Airshed Model, Technical Report. EPA-450/4-91-013, US Environmental Protection Agency, Office of Air Quality Planning and Standards, Research Triangle Park, NC, 1991.

Volkamer, R., Jiménez, J. L., San Martini, F., Dzepina, K., Zhang, Q., Salcedo, D., Molina, L. T., Worsnop, D. R., and Molina, M. J. : Secondary organic aerosol formation from anthropogenic air pollution: Rapid and higher than expected, Geophys. Res. Lett., 33, L17811, doi:10.1029/2006GL026899, 2006.

Weil, J. C., Sykes, R. I., and Venkatram, A.: Evaluating air-quality models: review and outlook, Appl. Meteo., 31, 1121-1145, 1992.

WHO: WHO air quality guidelines global update 2005, Bonn, Germany, World Health Organization, 2005.

Yttri, K. E. and Aas, W.: Transboundary Particulate Matter in Europe: Status Report 2006, EMEP Report, 2006.

Zhang, K., Knipping, E., Wexler, A., Bhave, P., and Tonnesen, G.: Size distribution of sea-salt emissions as a function of relative humidity, Atmos. Environ., 39, 3373-3379, 2005. 